\title{
The Earned Income Tax Credit:Targeting the Poor but Crowding Out Wealth is
}

\author{
Maren Froemel ${ }^{1}$, Charles Gottlieb ${ }^{2,3,4}$
}

\begin{abstract}
In this paper, we quantify the effects of the Earned Income Tax Credit (EITC) from a macroeconomic perspective. We analyze jointly the labor supply and saving responses to changes in tax credit generosity and their aggregate and distributional implications. Our results show that the EITC raises labor force participation, provides insurance to working poor households but also disincentivizes private savings for many. Whilst reducing post-tax earnings inequality, the EITC contributes to a higher skill premium and wealth inequality. Finally, EITC expansions are welfare improving for the majority of the population, both ex ante and when accounting for transitional dynamics.

Keywords: Fiscal Policy, Tax Credit Policy, Insurance, Transition.

JEL: E60, E62, H23, H24, I38.
\end{abstract}

\footnotetext{
«We would like to thank Árpád Ábrahám, Charles Brendon, Vasco Carvalho, Tiago Cavalcanti, Giancarlo Corsetti, Georg Duernecker, Elisa Faraglia, Chryssi Giannitsarou, Jan Grobovšek, Winfried Koeniger, Hamish Low, Ramon Marimon, Franck Portier, Ctirad Slavík and Hitoshi Tsujiyama for their comments as well as seminar participants at the French Macro Workshop, Konstanz University, St Gallen University, Cambridge University, York University Seminar and the EEA. A previous version of this paper was called "Asymmetric Transfers". We gratefully acknowledge financial support from the Keynes Fund of the University of Cambridge.

Email addresses: mf563@cam.ac.uk (Maren Froemel), charles.gottlieb@unisg.ch (Charles Gottlieb)

${ }^{1}$ Cambridge-INET Institute, University of Cambridge

${ }^{2}$ SEW, University of St. Gallen

${ }^{3}$ Centre for Macroeconomics (CFM), University of Cambridge

${ }^{4}$ Nuffield College
} 
Welfare programs subsidizing low income households are a defining feature of welfare states in advanced economies. While income support programs provide partial insurance against permanent and transitory income risks, they have adverse effects on individuals' incentives to work and save. To address this incentive problem, welfare states condition the eligibility to income support programs on the households' labor market participation, and provide tax credits to working households. For instance, in the United States the Earned Income Tax Credit (EITC) targets low income working individuals and tops up their labor earnings. The amount depends on individual taxable gross income and can be higher than their gross tax liability: the tax credit is refundable. The program thus encourages work and provides insurance against labor market risks by increasing tax progressivity for low income households.

The motivation for our analysis is threefold. First the EITC is the largest and fastest growing anti-poverty program in the United States ${ }^{5}$ and currently reaches more than a fifth of households. ${ }^{6}$ The EITC is widely credited to improve the well-being of households with low earnings, and to having lifted 9.1 million people out of poverty (Nichols and Rothstein, 2015). Second the EITC's share of the US federal budget, as of 2012, comes close to the share allocated to unemployment insurance (see figure A.10a). While the effects of unemployment insurance policies have been discussed at length in the literature, evidence on the EITC's distributional and aggregate effects is scarce given its policy relevance. Third, the existing literature on the EITC is largely silent about the EITC's insurance effect, its effects on savings, wealth inequality, and welfare. While such effects

\footnotetext{
${ }^{5}$ The EITC was started in 1975. As of 2012, refundable tax credits amount to $6 \%$ of the federal benefits to persons in the US, which comes close to the federal budget for unemployment insurance (see appendix).

${ }^{6}$ In 2015, about 27 million tax filers received EITC (https://www.eitc.irs.gov/EITC-Central/eitcstats).
} 
are widely discussed in the literature on optimal taxation and unemployment insurance, little is known about these aspects of tax credit policies. Since the aim of the EITC is to encourage labor force participation, the main focus of the literature has been on the labor supply effects of the EITC. Yet, the program size and the strength of the estimated labor supply effects suggest important price effects and call for a macroeconomic analysis of the EITC, which we are the first to provide.

The purpose of this paper is to quantify these effects. We evaluate how the EITC affects households' incentive to save and supply labor and provides insurance against labour market risks. Also, we analyze how tax credit generosity affects welfare both from an ex-ante and ex-post perspective. We proceed in three steps. First, we build a dynamic general equilibrium model of consumption, labor supply and savings decisions with permanent skill differences where individuals face risk to their labor productivity (Aiyagari, 1994; Huggett, 1993). We augment this model with non-linear taxes (net of EITC) on individual gross income and the EITC schedule. Second, we calibrate parameters of the model to replicate features of the US economy. Third, we conduct policy counterfactuals to analyze the effects of the EITC on individual behavior, distributions, aggregates and welfare. Our policy experiment consists in raising tax credit generosity. It mimics a source of exogenous variation, state-level EITC supplements to the federal rate, that is used in the empirical literature to identify behavioral responses to the EITC, thereby allowing us to contrast our results with existing empirical evidence.

Our results show that the EITC is a well targeted program: it improves households' insurance and welfare without reducing households' incentive to work. However, it reduces their incentives to save and leads to higher indebtedness among EITC recipients. We find that the labor supply margin is the most important one for the poorest households, but the intertemporal margin is more 
relevant for households on the phase-out range of the tax credit schedule. The predictions from our model are consistent with previous empirical findings and confirm that the policy contributes to an increase in the skill premium through a crowding in effect of low skilled labor supply. Furthermore, from an ex-ante perspective, an increase in EITC generosity in the currently implemented form of state supplements is a welfare enhancing policy for the majority of the population. It benefits poor households through a smoother consumption profile, but also richer households through a general equilibrium effect on their earnings.

The literature on the effects of the EITC is dense. Most papers, however, focus exclusively on labor supply responses to increases in EITC generosity in partial equilibrium environments with given wages. ${ }^{7}$ A key normative theoretical contribution is Saez (2002). He solves for the optimal income tax schedule in a standard static labor supply model and shows that the optimal transfer to poor households resembles the EITC if labor supply responses to cash transfers take place on the extensive margin. However, if the elasticities of labor supply are such that cash transfers lead to increases in labor supply on the intensive margin, then a negative income tax is optimal. The literature estimates these labor supply responses to increases in EITC generosity. This literature shows that households and individuals in the United States adjust their labor supply largely on the extensive margin and to a lesser extent via hours of work (Meyer and Rosenbaum, 2001; Rothstein, 2010; Eissa et al., 2008; Eissa and Liebman, 1996). ${ }^{8}$ Part of this lack of inten-

\footnotetext{
${ }^{7} \mathrm{An}$ comprehensive review of the literature on the EITC is provided by Nichols and Rothstein (2015).

${ }^{8}$ Eissa et al. (2008) document this fact for a sample of single mothers. They emphasize that the relative importance of the extensive and the intensive margin has first order welfare effects. Eissa and Liebman (1996) analyze the labor supply response of the Tax Reform Act of 1986 which encompassed an expansion of the EITC. Their identification strategy relies on comparing outcomes of single women without children with single women with children (who receive higher tax credits) and shows that labor force participation increases relatively more for single women with children, the strength of the response being negatively correlated with education. Importantly they do not find evidence that the EITC expansion decreases hours
} 
sive margin response among poor households can be accounted for by lack of information about the tax and transfer schedule (Chetty et al., 2013). There is a consensus in the literature that labor force participation is more elastic than hours worked to tax credit reforms in the United States (Blundell and Hoynes, 2004): if there is a labor supply response, it works at large via the extensive margin (Meyer, 2002, 2010; Eissa and Hoynes, 2006; Hotz and Scholz, 2003). Motivated by this unanimous empirical evidence for the United States our model features only the extensive margin of households' labor supply.

The identification of these statistically significant and large changes in labor participation raises the question whether and how equilibrium wages adjust in response to changes in EITC generosity. Leigh (2010) and Rothstein (2010) address this question empirically and show that wage effects are relatively large and statistically significant, in particular for unskilled labor. Rothstein (2010), for example, shows that single mothers and childless women lose $55 \%$ of the marginal EITC dollar due to reduced wages. Leigh (2010) estimates that an increase of $10 \%$ in EITC generosity leads to a 5\% drop of wages for high school dropouts, a $2 \%$ fall in wages those with high school diploma and has no effects on the wages of individuals with tertiary education. This evidence motivates our choice to analyze the distributive effects of the EITC though the lens of a general equilibrium model with permanent skill heterogeneity and endogenous wage distribution.

Beyond its intra-temporal effect on labor market participation and wages, tax credit policies should affect households' saving behavior for two reasons. First by changing the effective marginal tax rates schedule, the EITC alters household disposable income and should lead to changes in both labor supply and savings. Second, welfare programs in general affect the risk sharing properties of the

worked for people already in the labor force. 
economy and thereby households' precautionary savings motive (Hubbard et al., 1995; Feldstein, 1995). For example, Engen and Gruber (2001) show the importance of savings response to changes in unemployment insurance policies. Given this evidence, it seems pertinent to jointly allow tax credit reforms to affect savings behavior and labor supply. Recently, Blundell et al. (2015) account for the role of the intertemporal margin in a structural model of human capital accumulation and female labor supply and the role of the United Kingdom tax credit program. They emphasize both the insurance value of the tax credit for poor working women, as well as the negative effect on self-insurance. For the United States and the EITC, Weber (2014) finds that around 40 percent of the decline in the fraction of EITC recipients with savings in income bearing accounts can be explained by changes in EITC incentives, suggesting adverse effect on the individuals incentive to save.

The aforementioned empirical evidence and existing research suggests that an assessment of tax credit reforms should jointly allow for changes in the labor force composition, savings behavior and wage adjustments. We therefore develop a model that features the main behavioral and general equilibrium responses of the EITC identified in the empirical literature, based on which we conduct a welfare analysis of tax credit policies.

This paper is also related to the literature on the evaluation of policy reforms in inter-temporal choice models with heterogeneity. ${ }^{9}$ The literature on the tax reforms (Domeij and Heathcote, 2004; Heathcote, 2005), insurance effects of tax progressivity reforms (Conesa and Krueger, 2006; Conesa et al., 2009; Heathcote et al., 2014; Guner et al., 2012) and unemployment insurance (Engen and Gruber, 2001; Crossley and Low, 2011) is dense, but few papers look at transfer policy reforms (Athreya et al., 2014; Oh and Reis, 2012). Oh and Reis (2012) model

\footnotetext{
${ }^{9}$ An extensive review of this literature is provided in Heathcote et al. (2009).
} 
targeted transfers that are conditioned on household health and on their productivity. In their framework, targeted transfers are expansionary because they redistribute funds from healthy, high productivity workers towards low productivity workers. This redistribution has an expansionary effect since to finance those transfers, high productivity workers face a negative wealth effect which induces them to work more, while sick workers will reduce their labor supply. In contrast, our transfer is conditioned on persistent shocks to household productivity, giving an stronger role to private savings and hence crowding out effects. Athreya et al. (2014) highlight the insurance effect of the EITC for young unskilled women in a partial equilibrium environment. In particular, they show that the EITC reduces consumption volatility over the life cycle by 12 percentage points relative to an economy without transfer program. In contrast to Athreya et al. (2014) equilibrium wages are in our framework not policy invariant.

We contribute to both literatures. Beyond validating the effect of increased generosity on labor force participation and equilibrium wages highlighted by the empirical literature on the EITC, we analyze the EITC's effects on households' savings behavior. Overall the design of the EITC is well suited to circumvent the adverse effects of income support programs on the incentives to work, however it adversely affects the incentives to save and fosters wealth inequalities. Also our modelling exercise allows us to make welfare statements about the EITC and to contribute to the literature on fiscal policy. For a given income tax code that is calibrated to the US, we show that the EITC improves welfare by introducing more tax progressivity at the bottom of the income distribution. Conesa and Krueger (2006) show that tax deductions are a characteristic of an optimal progressive labor income tax. Our results suggest that tax credit policies such as the EITC step in for this missing progressivity of the tax code, and are one of the underlying policy instrument of the tax deductions advocated in 
Conesa and Krueger (2006).

The remainder of the paper is organised as follows: In section 1, we present our theoretical model and then proceed to our calibration strategy in section 2. We present the results from an extension of the tax credit in section 3, and conclude in section 4 .

\section{The Model}

The economy is populated by four types of agents: a continuum of households, a government, a representative firm and an external sector. Households supply labor to firms, consume a homogeneous good, and hold real risk-free assets. They differ in terms of skills and are subject to idiosyncratic shocks on their labor productivity. They self-insure by both borrowing or saving and working. Firms use the labor and capital supplied by households and the rest of the world, to produce the final good. They produce using a constant returns to scale technology and there is free entry in the goods market. The government pays out tax credit to working households that qualify, welfare to non-working households and taxes households' gross income non-linearly.

\subsection{Households}

The economy is populated by a continuum of infinitely-lived households that differ permanently in their skill level $(i=\{u, s\})$ : a mass of households $\pi^{u}$ is low-skilled and the complementary mass of households $\pi^{s}$ is high-skilled. Within each group, households draw labor productivity shocks $(\epsilon)$ from an $\mathrm{AR}(1)$ process characterized by its persistence $\rho_{i}$ and its variance $\sigma_{i}^{2}$. Beyond the permanent inequality, within each group, households are heterogeneous since their asset holdings reflect their individual history of labor productivity shocks. Households can partly self-insure against idiosyncratic productivity shocks by borrowing and saving in a non state-contingent asset $\left(a_{t}\right)$ and by supplying labor. The labor supply 
decision is binary: households either work full time $\left(\mathbf{1}_{t}=\{1,0\}\right)$, in which case they supply labor inelastically and obtain earnings according to the efficiency wage $\left(W_{i, t} \equiv w_{i, t} \epsilon\right)$ or they do not participate and obtain welfare transfer payments $(\omega)$. Savings and borrowing is subject to an interest rate $r_{t}$. Households can borrow up to an exogenous borrowing limit $(\underline{a})$. Households' net tax payments depends on their labor income and gross capital income $\left(D_{t} \equiv r_{t} a_{t}\right)$ and is determined by the function $T\left(W_{t}, D_{t}\right)$, which is the aggregate of a non-linear tax function on gross income and refundable tax credits, as detailed further in subsection 1.3.

Households derive utility from consumption $\left(c_{t}\right)$ and incur a group-specific utility $\operatorname{cost} q_{i}$ when working. We assume that instantaneous utility is of the CRRA type and also allow the subjective discount factor $\beta_{i}$ to be skill group specific. Households maximize expected life time utility subject to the infinite sequence of budget constraints (2 and 4$)$.

$$
\mathbb{E} \sum_{t=0}^{\infty} \beta_{i}^{t}\left(u\left(c_{t}\right)-q_{i} \mathbf{1}_{t}\right)
$$

where $\mathbb{E}$ is the mathematical expectations operator. If the household chooses to supply labor $\mathbf{1}_{t}=1$, its budget constraint reads:

$$
\begin{aligned}
c_{t}+a_{t+1} & =w_{i, t} \epsilon_{t}+\left(1+r_{t}\right) a_{t}-T\left(W_{t}, D_{t}\right) \\
a_{t+1} & \geq \underline{a}
\end{aligned}
$$

However, if the household decides to remain outside the labor force $\left(\mathbf{1}_{t}=0\right)$, he receives welfare $(\omega)$ and its budget constraint is as follows:

$$
\begin{aligned}
c_{t}+a_{t+1} & =\omega+\left(1+r_{t}\right) a_{t} \\
a_{t+1} & \geq \underline{a} .
\end{aligned}
$$


In each period, households choose their consumption $\left(c_{t}\right)$, whether to enter in the labor force $\left(\mathbf{1}_{t}\right)$ and asset holdings for the next period $\left(a_{t+1}\right)$ such that their budget constraint is satisfied. ${ }^{10}$

\subsection{Firms}

Firms operate a constant return to scale production technology and are perfectly competitive. They demand capital $K$ and labor $L$ to produce the final good, $Y$. Capital depreciates at the rate $\delta$ and its return $(R)$ is defined net of depreciation, $R=r-\delta$, where $R$ is the marginal product of capital.

$$
Y=K^{\alpha} L^{1-\alpha}
$$

We assume that firms use both high and low skilled labor. The labor types are imperfectly substitutable (Murphy and Katz, 1992). Aggregate labour input is thus defined as a composite of low skilled and high skilled labor. ${ }^{11}$

$$
L \equiv\left[\lambda L_{s}^{\rho}+(1-\lambda) L_{u}^{\rho}\right]^{1 / \rho} \quad, \rho \leq 1
$$

where $\epsilon=\frac{1}{1-\rho}$ is the elasticity of substitution between skilled labor $L_{s}$ and unskilled labor $L_{u}$ and $\lambda$ is a 'demand shifter'. Profit maximizing firms set wages to the marginal product of labor for both types, which gives rise to an endogenous skill premium.

\footnotetext{
${ }^{10}$ We focus on stationary equilibria, that is $r_{t}=r$ and drop time indices from now on.

${ }^{11}$ This production function is common in the literature on the macroeconomic implications of income inequality, but also structural change. Recent papers include Krueger and Ludwig (2015), Heathcote et al. (2010b), and Krusell et al. (2000). The latter are particularly interested in explaining the rise in the skill premium during the past decades, while Krueger and Ludwig (2015) analyze optimal tax progressivity.
} 


$$
w^{s}=(1-\alpha) k^{\alpha} \lambda\left(\frac{L}{L_{s}}\right)^{1-\rho}, \quad w^{u}=(1-\alpha) k^{\alpha}(1-\lambda)\left(\frac{L}{L_{u}}\right)^{1-\rho}
$$

The ratio of wages across skill groups determines the skill premium and its relationship with the ratio of skilled to unskilled labour $L_{s} / L_{u}$.

$$
\frac{w_{s}}{w_{u}}=\frac{\lambda}{1-\lambda}\left(\frac{L_{s}}{L_{u}}\right)^{\rho-1}, \quad \frac{\partial \frac{w_{s}}{w_{u}}}{\partial \frac{L_{s}}{L_{u}}}=(\rho-1) \frac{\lambda}{1-\lambda}\left(\frac{L_{s}}{L_{u}}\right)^{\rho-2}
$$

The skill premium is unambiguously decreasing in the ratio of skilled to unskilled labour supply. The decrease is an increasing function of complementarity: the more complementary the two labor inputs are, the more will wages change as a result to a change in labor supply or labor demand.

\subsection{Government}

The government taxes Adjusted Gross Income (AGI), distributes tax credits to working households and welfare to non-working households. The overall nettax payment function $(T(W, D))$ summarizes the income tax and the tax credit, where $W$ denotes labor income, $D$ dividends, and $A G I$ is the sum of both sources of income.

$$
\begin{array}{r}
T(W, D)=\tau(A G I) A G I-\Upsilon(W, D), \\
\text { where } W \equiv w \epsilon, \quad D \equiv r a, \quad A G I=w \epsilon+r a
\end{array}
$$

The ingredients of the net tax function are a non-linear taxation function $\tau(A G I)$, and the Earned Income Tax Credit schedule $\Upsilon(W, D)$. The tax function $\tau(A G I)$ is a smooth approximation of the income tax schedule net of any welfare programs such as the EITC. The average tax rate is shown in equation (7), and the marginal tax rate in equation (8). 


$$
\begin{gathered}
\tau(A G I)=b\left(1-\left(s A G I^{p}+1\right)^{\frac{-1}{p}}\right) \\
\tilde{\tau}(A G I)=b\left(1-\left(s A G I^{p}+1\right)^{\frac{-1}{p}-1}\right)
\end{gathered}
$$

The tax credit schedule $\Upsilon(W, D)$ is parametrized based on data from the 2010 EITC schedule as reported by the Internal Revenue Service (IRS). In figure 1, we show (a) the EITC schedule as a function of income, (b) the effect of the EITC on the effective average tax rate, and (c) the transfer to income ratio of the EITC, for the relevant range of income levels. The tax credit schedule $(\Upsilon(W, D))$ is defined by six parameters. The parameters $\alpha_{i n}$ and $\beta_{i n}$ are the intercept and the slope of the phase-in region of the tax credit function. In the phase-in region of the tax credit function is an increasing function of $A G I$. It ends for income levels above $\underline{T}$. For income levels $A G I \in[\underline{T}, \bar{T}]$ households perceive the maximum level of Tax Credit which is denoted $\bar{\Upsilon}$; this corresponds to the so-called plateau region of the EITC. For the income levels $A G I \in[\bar{T}, \widehat{T}]$, the Tax Credit pay-off is decreasing and determined by $\alpha_{\text {out }}$ and $\beta_{\text {out }}$, the intercept and the slope of the linear function that describes the so-called phase-out region of the EITC. Note that both the income level at which the phase-out starts $\bar{T}$ and ends $\widehat{T}$ are a function of the EITC policy parameters.

$$
\Upsilon(W, D)= \begin{cases}\alpha_{\text {in }}+\beta_{\text {in }} A G I & \text { if } \underline{T}>A G I>0 \\ \bar{\Upsilon} & \text { if } \bar{T} \geq A G I \geq \underline{T} \\ \alpha_{\text {out }}+\beta_{\text {out }} A G I & \text { if } \widehat{T}>A G I>\bar{T} \\ 0 & \text { if } A G I \geq \widehat{T}\end{cases}
$$

where $\underline{T}=\frac{\bar{\Upsilon}-\alpha_{\text {in }}}{\beta_{\text {in }}}, \bar{T}=\frac{\bar{\Upsilon}-\alpha_{\text {out }}}{\beta_{\text {out }}}, \widehat{T}=\frac{-\alpha_{\text {out }}}{\beta_{\text {out }}}$. Also the EITC pay-off is asset-tested: if a households whose AGI is within the bounds for EITC eligibility, but has a 
capital income that is above a threshold level of $\bar{D}$, then that household looses its EITC eligibility.

$$
\Upsilon(W, D)=0, \text { if } \quad r a>\bar{D}
$$
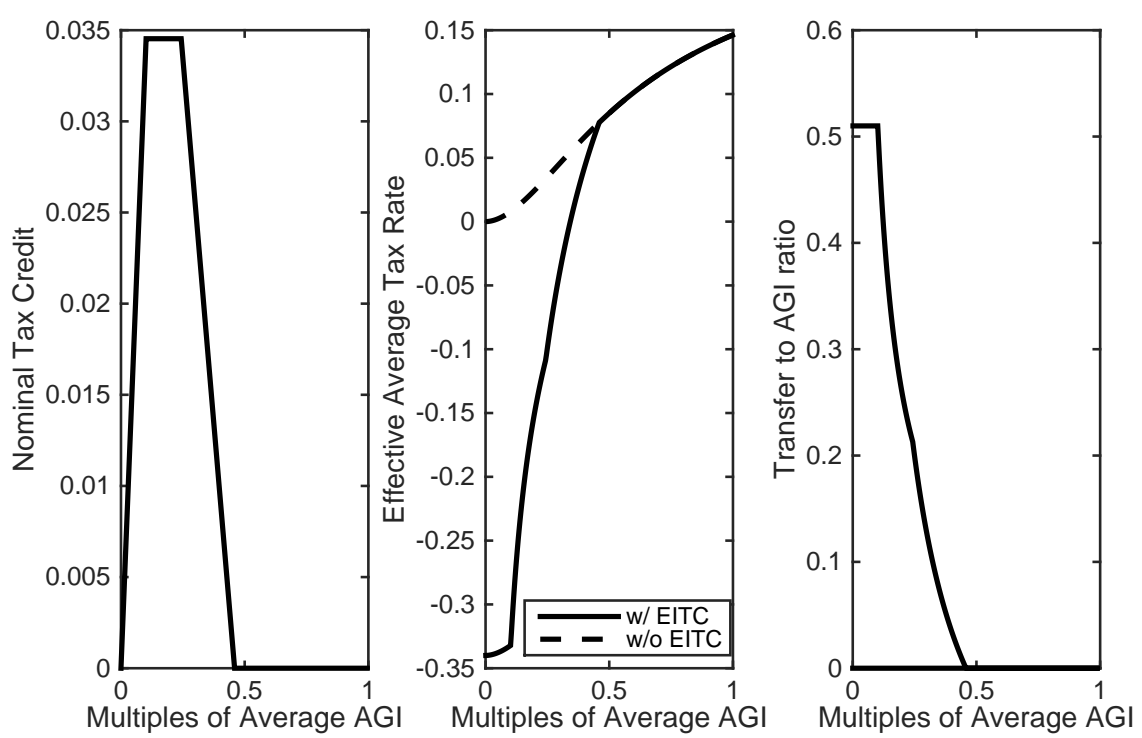

Figure 1: EITC and its effect on the average tax rate.

Government spending $G$ is the sum of net tax payments, welfare expenditure and transfer payments:

$$
G=\int_{I x A x E} \mathbf{1}(i, a, \epsilon) T(W, D) d \lambda(i, a, \epsilon)-\int_{I x A x E}(1-\mathbf{1}(i, a, \epsilon)) \omega d \lambda(i, a, \epsilon)
$$

where $\omega$ denotes welfare transfer payments and IxAxE with $I: i \in\{s, u\}, a \in$ $[\bar{a}, \infty), \epsilon \in E$ is the cartesian product of the possibility sets of skill levels, assets, and productivity levels for all households in the economy:

\subsection{Small open economy}

We assume that the economy is small and that capital is perfectly mobile. The domestic real interest rate is constant and equals to the world interest rate 
$r$. Hence, the marginal productivity of capital is equal to the world real interest rate net of depreciation:

$$
r-\delta=\alpha k^{\alpha-1}=\alpha \frac{Y}{K},
$$

where $Y$ is aggregate output and $K$ is total capital used in production. This implies that the capital output ratio is determined by the real interest rate $r$, the depreciation rate $\delta$ and the capital share $\alpha$. Given the definition of the production function, the capital labour ratio $(k)$ is also constant and given by:

$$
k=\frac{K}{L}=\left(\frac{r+\delta}{\alpha}\right)^{\frac{1}{\alpha-1}} .
$$

Since we assume free capital mobility, $K=k L$ is positively and linearly related to aggregate labor supply. The real interest rate $r$ cannot adjust to equate demand for capital and aggregate domestic savings $K^{\text {dom }}$. Firms will demand capital from the rest of the world, if aggregate savings fall short of demand; if savings exceed capital demand, households will save abroad. Hence, domestic savings are a fraction of the total capital stock used in production $K^{\text {dom }}=(1-\vartheta) K .^{12}$

The aggregate resource constraint of this economy is given by the following equation:

$$
C+I+G+N X=Y
$$

After aggregating the budget constraint of the continuum of households, and using the fact that net exports (or the current account) amount to the difference

\footnotetext{
${ }^{12}$ Strictly speaking, it is indeterminate whether firms will use foreign or domestic capital in production because capital is perfectly substitutable irrespective of its origin. Only net figures, i.e. the capital account balance, are determined. For simplicity, we assume that firms first use domestic, then foreign capital.
} 
between current capital inflows $(1-\vartheta) K$ (as this is an export) and repayments $(1-\vartheta)(1+r) K$ (plus interest, at the given world interest rate), the following equation must hold in equilibrium.

$$
(1-\vartheta)(K-(1+r) K)=-(1-\vartheta)(\alpha Y-\delta K)
$$

\subsection{Recursive Formulation of the household problem}

The household maximization problem can be written recursively as a function of his state variables $(i, a, \epsilon) . V(i, a, \epsilon)$ denotes the discounted expected life-time utility of a household with asset holdings $a$, labor productivity $\epsilon$ and skill type $i$. Since the decision to work is a discrete choice, the value function $V(i, a, \epsilon)$ is obtained by taking the maximand between the indirect utility from working and the indirect utility from not working.

$$
V(i, a, \epsilon)=\max _{\mathbf{1}=[0,1]}[V(i, 1, a, \epsilon) ; V(i, 0, a, \epsilon)]
$$

$\mathbf{1}(i, a, \epsilon)$ is the policy function for household's decision whether or not to participate in the labor market.

$$
\mathbf{1}(i, a, \epsilon)= \begin{cases}0 & \text { if } V(i, 0, a, \epsilon)>V(i, 1, a, \epsilon) \\ 1 & \text { else. }\end{cases}
$$

The indirect utility a household that supplies labor is computed as follows.

$$
\begin{aligned}
V(i, 1, a, \epsilon) & =\max _{a^{\prime}, c} u(c)-q_{i}+\beta_{i} \int_{\epsilon^{\prime} \in \Omega} V\left(i, a^{\prime}, \epsilon^{\prime}\right) f\left(\epsilon, \epsilon^{\prime}\right) d \epsilon^{\prime} \\
\text { s.t. } \quad c+a^{\prime} & =w_{i} \epsilon+(1+r) a-T(W, D) \\
a^{\prime} & \geq \underline{a}
\end{aligned}
$$


The dynamic program of a labor market non-participant is as follows.

$$
\begin{aligned}
V(i, 0, a, \epsilon) & =\max _{a^{\prime}, c} u(c)+\beta_{i} \int_{\epsilon^{\prime} \in \Omega} V\left(i, a^{\prime}, \epsilon^{\prime}\right) f\left(\epsilon, \epsilon^{\prime}\right) d \epsilon^{\prime} \\
\text { s.t. } \quad c+a^{\prime} & =\omega+(1+r) a \\
a^{\prime} & \geq \underline{a}
\end{aligned}
$$

As highlighted in section 1.3, the amount of transfers distributed by the government depend on the households' choice variables 1 and $a$. The household internalizes the transfer rule in her decision-making, which is reflected in the following intertemporal optimality condition of the household problem.

$$
u^{\prime}(c)=\beta_{i}(1+r-\partial T(W, D) / \partial D) \mathbb{E} u^{\prime}\left(c^{\prime}\right)+\mu, \quad \mu \geq 0 .
$$

where $\mu$ denote the Lagrange multiplier on the borrowing constraint. The households' intertemporal optimal condition dictates that whenever the borrowing constraint is binding, ceteris paribus current marginal utility from consumption is higher and consumption is lower than when the constraint does not bind. As the tax credit is contingent on households' capital income, it directly impacts the return on capital which becomes household specific. If $T_{D}<0$, that is, if the tax credit benefits low asset holders, the household faces a tax on asset holdings and internalizes this into the optimal investment choice. A steep transfer function ceteris paribus translates into lower savings and higher current consumption. On the other hand, in the presence of such a tax credit, a credit constrained household benefits from receiving a higher transfer, which reduces his consumption volatility. ${ }^{13}$

\footnotetext{
${ }^{13}$ The first order condition is outlined here to develop intuition. Given the non-linearities of the EITC schedule, our numerical algorithm uses the value function iteration method and not
} 
Stationary Competitive Equilibrium Given a borrowing limit $\underline{a}$, an exogenous interest rate $r$, an income tax schedule $\tau(W+D)$ and a transfer allocation rule $\Upsilon(W, D)$, a stationary competitive equilibrium is a set of positive wages $w_{i}$ by skill type, a positive quantity of aggregate labour supply $L$ and capital supply $K$, time invariant decision rules $a^{\prime}(i, a, \epsilon), \mathbf{1}(i, a, \epsilon)$ and a probability distribution $\lambda(i, a, \epsilon)$ such that:

1. Equilibrium wages $w_{i}$ satisfy the static optimization problem of the representative firm formulated in section 1.2

2. The policy functions $c(i, a, \epsilon), a^{\prime}(i, a, \epsilon), \mathbf{1}(i, a, \epsilon)$ solve the household maximization problem formulated in section 1.5

3. The probability distributions $\lambda(i, a, \epsilon)$ are stationary distributions s.t.

$$
\lambda\left(i, a^{\prime}, \epsilon^{\prime}\right)=\int_{\epsilon} \int_{a: a^{\prime}(i, a, \epsilon)} \lambda(i, a, \tilde{\epsilon}) d f\left(\tilde{\epsilon}^{\prime} \mid \tilde{\epsilon}\right)
$$

4. The labor market clears, such that aggregate effective labor equals the sum of all individual hours supplied multiplied by their respective productivity:

$$
L=\int_{\underline{a}}^{\bar{a}} \int_{\epsilon} \int_{i=u, e} \mathbf{1}(i, \tilde{a}, \tilde{\epsilon}) n(i, \tilde{a}, \tilde{\epsilon}) \epsilon \lambda(i, a, \tilde{\epsilon}) d \tilde{a} d \tilde{\epsilon} d i .
$$

5. The government taxes labor and redistributes via tax credits and welfare. Government spending $(G)$ amounts to the gap between tax revenues and transfers, as in equation (9).

6. The good market clears, such that aggregate output is the sum of consumption, investment, government spending, investment and net exports.

$$
N X=-(1-\vartheta)(\alpha Y-\delta K)
$$

the first order condition method as the above equation may suggest. 
where $\vartheta$ is the fraction of the total capital stock that is domestic.

7. By Walras Law, the capital market clears.

\section{Parametrization}

In this section we lay down our calibration strategy. We first document the parameters that are fixed outside the model and subsequently explain the data targets sought for the remaining parameters. Finally we show how the model performs for moments that are not targeted.

\subsection{Idiosyncratic Productivity Shocks}

In the model, we assume that households differ permanently in their skill level. They can either be 'high skilled' or 'low skilled'. Following previous literature, we assume that 'high skilled' households are those with education beyond a high school degree. Consequently, 'low skilled' households have education lower than or equal to a high school degree. The parameters of the AR(1) process for the idiosyncratic labor productivity for both subgroups are taken from Krueger and Ludwig (2015). ${ }^{14}$ We then parametrize the process for $\epsilon$ by discretizing the $\mathrm{AR}(1)$ process for both groups into a ten state Markov Chain following Tauchen (1986).

\begin{tabular}{ccc}
\hline & Value & Source \\
\hline \hline$\rho_{s}$ & 0.969 & Krueger \& Ludwig (2015) \\
$\rho_{u}$ & 0.928 & Krueger \& Ludwig (2015) \\
$\sigma_{s}$ & 0.100 & Krueger \& Ludwig (2015) \\
$\sigma_{u}$ & 0.141 & Krueger \& Ludwig (2015) \\
$\pi_{s}$ & 0.450 & CPS 2010 \\
$\pi_{u}$ & 0.550 & CPS 2010 \\
\hline
\end{tabular}

Table 1: Heterogeneity parameters

\footnotetext{
${ }^{14}$ Table 3 in Krueger and Ludwig (2015).
} 


\subsection{Tax function and EITC schedule}

The parameters of the income tax function are taken from Guner et al. (2013). Based on recent micro data from the U.S. Internal Revenue Service, they provide parametric estimates of effective tax functions. For the purpose of our paper, it is essential to obtain a tax function net of EITC, so that we can model explicitly the EITC schedule, and thereby isolate the effect of changes in the EITC program. Guner et al. (2013) test several approximations that are used in the literature on recent U.S. household data from the Internal Revenue Services 'Public Use Tax File'. Guner et al. (2013) emphasize that the Gouveia and Strauss (1994) approximation matches best the average tax schedule of the US, in particular for households with annual incomes ranging from the mean of US household income up to 3 means of household income. However, the Gouveia and Strauss (1994) approximation fails to compute negative tax schedules and matches poorly the tax incidence for households at the bottom of the earnings distribution. Our approach combines the Gouveia and Strauss (1994) approximation with an explicit modelling of the EITC, and thereby allows us to deliver a good fit of the effect of tax incidence and progressivity both at the bottom and in the middle of the income distribution. The Gouveia and Strauss (1994) tax function is described in section 1 and restated below (equations $11-12$ ).

$$
\begin{gathered}
\tau(A G I)=b\left(1-\left(s A G I^{p}+1\right)^{\frac{-1}{p}}\right) \\
\tilde{\tau}(A G I)=b\left(1-\left(s A G I^{p}+1\right)^{\frac{-1}{p}-1}\right)
\end{gathered}
$$

Table 2 reports their parameter estimates of the 'GS' (Gouveia-Strauss) approximation to the tax function for married households. ${ }^{15}$ We focus on married

\footnotetext{
${ }^{15}$ Table 10 in Guner et al. (2013).
} 
households, since they represent $62.3 \%$ of U.S. individuals (CPS, 2010). ${ }^{16}$ Also we can confidently assume that they all file jointly: $94.77 \%$ of married household file taxes jointly (CPS, 2010) allowing us to select the EITC schedule for joint tax filers. Although we model only one type of household, our tax system is representative at the aggregate level since we capture accurately the tax system for over 60 percent of the population.

\begin{tabular}{ccc}
\hline & Value & Source \\
\hline \hline$\alpha_{\text {in }}$ & 0 & IRS 2010 \\
$\beta_{\text {in }}$ & 0.34 & IRS 2010 \\
$T$ & 3162 & IRS 2010 \\
$\alpha_{\text {out }}$ & 6727.91 & IRS 2010 \\
$\beta_{\text {out }}$ & -0.16 & IRS 2010 \\
$\bar{D}$ & 3100 & IRS 2010 \\
\hline$b$ & 0.247 & Guvenen et al. (2013) \\
$s$ & 0.001 & Guvenen et al. (2013) \\
$p$ & 1.850 & Guvenen et al. (2013) \\
\hline
\end{tabular}

Table 2: Taxation Parameters

The amount of tax credit a tax filer is eligible to claim depends on his gross earned income, individual filing status, on the number of dependent children as well as on individuals' capital income, which must not exceed a threshold (USD 3'100 in 2010). The six parameters that determine the EITC schedule and the capital income limit $(\bar{D})$ are taken from the tax code (IRS) and reported in table 2. They describe the EITC schedule for married households that file taxes jointly, as argued above, and have one qualifying child in 2012. We choose to focus on the EITC schedule with one qualifying child, since it corresponds to the median number of children under 18 in married households that file taxes jointly (CPS 2010 - average is at 1.27). We focus on this category of household with the aim to match an 'average' EITC recipient. Overall, the tax credit schedule

\footnotetext{
${ }^{16}$ Interestingly from the remaining $37.7 \%$ of U.S. individuals $81.3 \%$ (or $30.55 \%$ of the U.S. individuals) are unmarried or non-family female households. So far the EITC literature has almost exclusively focused on this household type.
} 
is characterized by three regions: the phase-in, the plateau and the phase-out range. In the phase-in range, the transfer increases with earned income, in the plateau region it is constant, and it falls in the phase-out range as shown in figure A.11.

\subsection{Calibration}

In this subsection we document how we calibrated the remaining parameters. The type dependent utility cost of participating in the labor market $\left(q_{i}\right)$ is set to match the fraction of high and low skilled households working full time during the past year. The subjective discount factors $\left(\beta_{i}\right)$ target the relative wealth across skill types that is observed in the United States, as reported in Slavík and Yazici (2014), and the fraction of indebted households which is based on SCF (2010) data. To compute the fraction of indebted households, we proceed as in Ábrahám and Cárceles-Poveda (2010) and exclude non-financial assets and secured debt from our measure of wealth since our model is tailored towards liquid financial assets. Based on this empirical measure of wealth we compute the fraction of households with negative wealth. The labor demand shifter $(\lambda)$ in the production function is used to generate a wage skill premium of 1.80 , as documented in Heathcote et al. (2010a). The parameter determining welfare payments $(\omega)$ is chosen such that they amount to $20 \%$ of mean household income as reported in Holter et al. (2014). The elasticity of substitution across labor skill types is taken from Murphy and Katz (1992). The depreciation rate $\delta$ is chosen to amount to 0.08 , so that the capital to output ratio amounts to 3 . And the capital share $(\alpha)$ is set to 0.33 , since US data suggests a labor share of 0.66 .

The two remaining parameters, the real interest rate and the risk aversion

parameter $(r, \gamma)$, are set exogenously. We set an annual interest rate of $3 \%$, and 


\begin{tabular}{ccccc}
\hline & Value & Target & Value & Source \\
\hline \hline$q_{s}$ & 0.558 & Labor Force Participation & 0.85 & CPS 2010 \\
$q_{u}$ & 1.028 & Labor Force Participation & 0.70 & CPS 2010 \\
$\beta_{s}$ & 0.970 & Relative Wealth & 2.68 & Slavik \& Yacizi (2014) \\
$\beta_{u}$ & 0.965 & Fraction of indebted HH & 0.29 & SCF 2010 \\
$\lambda$ & 0.633 & Skill Premium & 1.80 & Heathcote et al. (2010) \\
$\omega$ & 0.116 & Welfare \% of mean income & 0.20 & Holter et al. (2015) \\
\hline$\delta$ & 0.080 & Capital-Output Ratio & 3.00 & \\
$\alpha$ & 0.330 & Labor Share & 0.66 & Katz \& Murphy (1992) \\
$\rho$ & 0.310 & Elas. of substitution & 1.45 & fixed \\
\hline$\gamma$ & 1.500 & Risk Aversion & & fixed \\
$r$ & 0.030 & Interest Rate & & \\
\hline
\end{tabular}

Table 3: Calibration - Model with extensive margin

choose a coefficient of relative risk aversion of $1.5 .^{17}$

\section{Results from an expansion of the EITC}

We quantify the effects of tax credit policies such as the EITC by conducting the following policy experiment: for a constant gross income range of tax credit eligibility that is calibrated to the data, we increase the amount of tax credit paid out, i.e. we vary the generosity of the tax credit program. We model this increase in generosity by multiplying the calibrated EITC schedule $\Upsilon(W, D)$ by a factor $(1+\eta)$. This modeling choice is guided by an institutional setup that prevails in the United States: it mimics the state tax credit supplement programs that exist in most US states. While keeping the range of eligibility for earned income and the asset test at the federal level, state tax credit supplements top up the federal tax credit by a percentage $\eta$ that varies across states. ${ }^{18}$ Doing so allows us to compare our results with the empirical evidence provided by Leigh (2010), since our policy experiment replicates the source of exogenous variation that he

\footnotetext{
${ }^{17}$ Results for the model with a high degree of risk aversion are available upon request.

${ }^{18}$ In some cases, this supplement is conditional on number of children and filing status. Current state supplements can be found here: <click to go to IRS section on this topic $>$.
} 
uses to empirically identify labor supply and wage effects of increased tax credit generosity. ${ }^{19}$

By supplementing the tax credit paid out, the policy experiment effectively changes the progressivity of the tax schedule for the income range of eligible households. In the left panel of figure 2, we show for illustrative purposes how the transfer schedule is affected when tax credit generosity is increased by $50 \%$ $(\eta=0.5)$. In the right panel, we illustrate the effect of increased EITC generosity on the effective average tax schedule, and the corresponding increase in tax progressivity. In the benchmark economy $(\eta=0)$, the implied transfer to income ratio for eligible low income households is about $30 \%$ and it increases to around $50 \%$ when tax credit generosity is increased by $50 \%(\eta=0.5) .{ }^{20}$
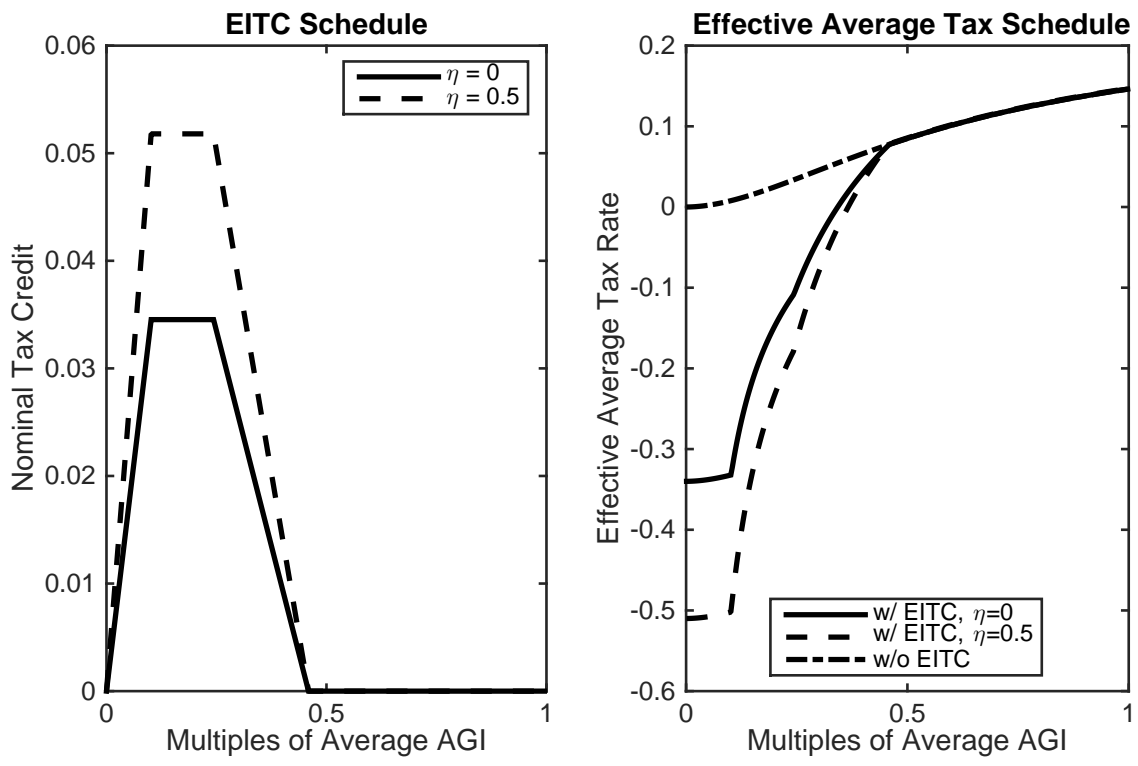

Figure 2: Effect of EITC expansion on transfer (left) and average tax (right) schedule.

The discussion of the results proceeds as follows. In section 3.1, we describe

\footnotetext{
${ }^{19}$ Leigh (2010) quantifies the effect of increase tax credit generosity on labor supply and wages by exploiting using the variation across states of state tax credit supplement.

${ }^{20}$ Trivially the effective average tax schedule without EITC does not allow for negative tax rates since the income tax schedule is approximated using the Gouveia and Strauss (1994) specification.
} 
the effects on aggregates, distributions, and individual decisions both across stationary equilibria as well as accounting for transitional dynamics. Section 3.2 provides a discussion of the welfare implications of the tax credit reforms.

\subsection{Aggregate and distributional effects}

We proceed with a discussion of the effects of increases in tax credit generosity on allocations across stationary equilibria (ex post results) in section 3.1.1. We then complete our analysis by documenting in section 3.1.2 the economy's behavior on the transition path from the initial steady state to the post-reform equilibrium after a once and for all expansion of the tax credit policy.

\subsubsection{Ex post results - across stationary equilibria}

In the first column of table 4, we report the statistics of the calibrated economy. In the remaining columns we show the effect of an expansion for three level of generosity $(\eta)$, and for each of which we show how the results vary for three financing scenarios ('cases'). We first analyze the effect of an unfunded tax credit expansion (i.e. adjustments happen via government spending), reported as 'Case 1', before considering two financing scenarios and their implications for the results in the next paragraph.

An expansion of tax credit generosity increases labor market participation across skill groups, however more so for low skilled households than high skilled households. The total effect on labor market participation is $0.85 \%$. Since skill types are imperfectly substitutable in production, the wage response of increased tax credit generosity differs across skill groups. The share of low skilled relative to high skilled workers in the labor force is higher, which reinforces this effect. The wage level of low skilled labor falls by 0.42 percentage points (p.p.) if tax credit generosity is increased by $10 \%$, whereas the wage level of high skilled labor increases by 0.25 p.p., thereby increasing the skill premium. Empirical estimates 
by Leigh (2010) and Rothstein (2010) support the qualitative predictions of our model on the effect of EITC on labor force composition and equilibrium wages (see table 4 and 5 in Leigh (2010), and table 3 in Rothstein (2010)). Labor supply rises as a result of two effects. First directly via tax credit: a lower effective tax rate raises the incentive to supply labor. Second indirectly as households supply more labor since they save less when tax credit policies are more generous.

\begin{tabular}{|c|c|c|c|c|c|c|c|c|c|c|}
\hline Variable & SS Value & & $\eta=0.1$ & & & $\eta=0.25$ & & & $\eta=0.5$ & \\
\hline- & - & Case 1 & Case 2 & Case 3 & Case 1 & Case 2 & Case 3 & Case 1 & Case 2 & Case 3 \\
\hline GDP & 0.69 & 0.45 & 0.46 & $\overline{0.48}$ & 1.03 & 1.08 & 1.18 & 2.20 & 2.33 & 2.57 \\
\hline Savings (LS) & 0.99 & -4.69 & -4.83 & -4.75 & -10.71 & -11.07 & -11.00 & -23.33 & -23.89 & -23.77 \\
\hline Savings (HS) & 2.65 & -0.51 & -0.57 & -0.90 & -1.32 & -1.71 & -2.70 & -2.27 & -3.16 & -5.92 \\
\hline Participation (LS) & 0.38 & 1.60 & 1.62 & 1.62 & 3.92 & 4.00 & 4.01 & 8.46 & 8.59 & 8.61 \\
\hline Participation (HS) & 0.38 & 0.12 & 0.13 & 0.18 & 0.29 & 0.36 & 0.53 & 0.55 & 0.72 & 1.18 \\
\hline Relative wealth & 2.68 & 4.38 & 4.47 & 4.04 & 10.51 & 10.52 & 9.33 & 27.47 & 27.23 & 23.43 \\
\hline Fraction $\mathrm{HH}$ in debt & 0.29 & 3.43 & 3.46 & 3.54 & 9.36 & 9.66 & 9.74 & 20.39 & 20.75 & 21.31 \\
\hline Wage (LS) & 0.41 & -0.42 & -0.42 & -0.41 & -0.95 & -0.95 & -0.90 & -2.07 & -2.05 & -1.90 \\
\hline Wage (HS) & 0.74 & 0.25 & 0.25 & 0.24 & 0.57 & 0.57 & 0.54 & 1.26 & 1.24 & 1.15 \\
\hline Total Transfer (\% GDP) & 0.83 & 13.66 & 13.68 & 13.65 & 35.34 & 35.45 & 35.30 & 76.45 & 76.53 & 75.98 \\
\hline
\end{tabular}

Table 4: Aggregate effects of Tax Credit policies (percentage point deviations from the calibrated steady state (SS) value).

Both high skilled and low skilled labor reduce their level of savings (see figure 6). As a result households are on average poorer, more households are borrowing constrained and have negative net wealth (figure 5). Weber (2014) shows empirically that the EITC reduces the incentive to save among EITC recipients in the US, further validating the behavioral responses of our model. Further below, we show the fall in savings for low skilled households is due to two effects: lower earnings and improved public insurance. For a large part of the population the second effect dominates: Public insurance in the form of higher tax credits crowds out private insurance.

The drop in savings is more pronounced for low skilled than high skilled households thereby generating an increase in relative wealth. This is mainly because low skilled households are more likely to receive the transfer and if so, they receive a higher amount. There is also an indirect channel through the 
general equilibrium effect on wages: For low skilled households, the labor earnings effect and the effect of an increased tax credit are both negative whereas for high skilled households the labor earnings effect is positive, since their wage level is higher as a result of increased tax credit generosity (see figure 4). With regard to economic aggregates, increased tax credit generosity raises output since labor supply rises and thereby also the demand for capital by domestic firms. Capital supply can be matched via an increased foreign capital supply at a constant interest rate $r$.

A permanent increase in EITC generosity raises GDP and raises labor force population, but so far we were silent as to how these expansion are funded. In the following paragraph, we address this issue and show that our results are robust to two financing scenarios.

\begin{tabular}{|c|c|c|c|c|c|c|c|c|c|c|}
\hline Variable & SS Value & & $\eta=0.1$ & & & $\eta=0.25$ & & & $\eta=0.5$ & \\
\hline- & - & Case 1 & Case 2 & Case 3 & Case 1 & Case 2 & Case 3 & Case 1 & Case 2 & Case 3 \\
\hline EITC take-up (LS) & 0.405 & 0.421 & 0.421 & 0.421 & 0.440 & 0.441 & $\overline{0.441}$ & $\overline{0.479}$ & $\overline{0.480}$ & $\overline{0.480}$ \\
\hline EITC take-up (HS) & 0.202 & 0.202 & 0.202 & 0.203 & 0.203 & 0.204 & 0.205 & 0.204 & 0.205 & 0.207 \\
\hline Transfer to AGI Ratio (LS) & 0.031 & 0.036 & 0.036 & 0.036 & 0.045 & 0.045 & 0.045 & 0.062 & 0.062 & 0.062 \\
\hline Transfer to AGI Ratio (HS) & 0.010 & 0.011 & 0.011 & 0.011 & 0.012 & 0.012 & 0.012 & 0.014 & 0.014 & 0.014 \\
\hline Gini Wealth & 0.756 & 0.766 & 0.766 & 0.766 & 0.778 & 0.779 & 0.779 & 0.802 & 0.804 & 0.805 \\
\hline Gini Earnings & 0.408 & 0.407 & 0.407 & 0.407 & 0.405 & 0.405 & 0.405 & 0.402 & 0.401 & 0.400 \\
\hline Gini Earnings Post & 0.372 & 0.369 & 0.369 & 0.369 & 0.365 & 0.365 & 0.364 & 0.357 & 0.356 & 0.354 \\
\hline
\end{tabular}

Table 5: Distributive effects of Tax Credit policies (\% deviations from the calibrated steady state (SS) value).

Financing scenarios. We distinguish between three financing scenarios, which we label 'cases' in tables 4-5 and figures 3-5. In the first financing scenario (Case 1), the tax credit expansion is unfunded, i.e. the increase in transfer expenditures is matched by an increase or decrease in government consumption $G$. At this stage, it is important to emphasize that the effect on government consumption is ambiguous - an expansion of the EITC can potentially be self-financed and lead to an increase in government consumption. In fact, welfare expenditures are likely to fall since the tax credit expansion leads to an increase in labor force 
participation and the nominal value of welfare payments $\omega$ is kept constant across experiments. ${ }^{21}$ Tax revenues may fall or rise, depending on how the distribution of households responds to changes in tax credit generosity.

In the benchmark equilibrium, $G$ as a fraction of output is $5.4 \%{ }^{22}$ Without adjustment in tax rates, $G$ drops by 0.3 p.p for $\eta=0.1$ and by up to 2.05 p.p for $\eta=0.5$. Because output increases, the fall in the ratio of $G$ to output is magnified: $\frac{G}{Y}$ drops to $5.17 \%$ when $\eta=0.5$. However, the fall in government spending is less than the increase in transfer spending (by about 1\% of GDP or a $13.6 \%$ increase from the benchmark EITC budget when $\eta=0.1$ ), hence the tax credit expansion is partly self financed. Welfare receipts fall by more than any other spending category due to higher labor force participation ( $0.8 \%$ of GDP or $2.8 \%$ from their previous level), while tax revenues fall by a moderate amount (by $0.05 \%$ ). This reduction in receipts is entirely due to the crowding out effect on savings, as households do not choose hours worked, only participation, and average income actually increases.

In the second financing scenario ('Case 2'), the tax credit expansion is financed by an overall increase in the average tax rate for the entire population which increases equally the marginal tax rate for all households. ${ }^{23}$ In 'Case 3 ' the expansion is financed by a targeted increase in the tax rate: in this scenario the average and marginal tax rates is adjusted only for households with an adjusted gross income above the mean $(A G I>\overline{A G I})$. In this scenario, increased tax progressivity at the bottom of the earnings distribution is financed by increased progressivity at the top. Figure 3 shows how the average tax schedule changes in

\footnotetext{
${ }^{21}$ The nominal anchor of the tax function, i.e. average income, is kept constant across experiments as we want people with the same nominal income across economies to pay the same nominal amount of taxes.

${ }^{22}$ As discussed in section $1, G$ is a residual and we abstract from government debt, contributions other than income taxes, and government investment.

${ }^{23}$ This scenario corresponds to an increase in the value of parameter $b$ in equation 11
} 

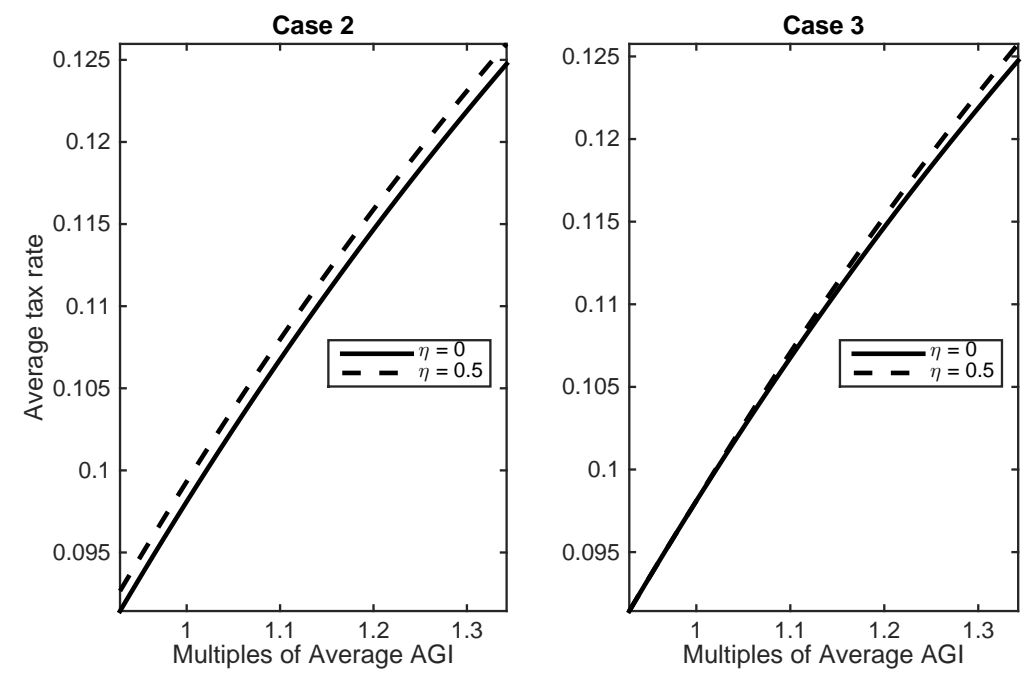

Figure 3: Change in average tax schedule $\tau(A G I)$ to finance transfer expansion

both financing scenarios using a $50 \%$ increase in tax credit generosity $(\eta=0.5)$ as an example.

We contrast the effects of increased generosity across financing scenarios ('cases') in the respective columns of table 4. Overall, the effects prevail independently of whether the tax generosity increase is financed or not, and of how it is financed. The magnitude of the effects changes slightly. The labor supply responses are systematically larger for both skill groups when the tax credit expansion is financed by an increase in level of the overall tax schedule (Case 2) or by an increase in progressivity (Case 3). However, the savings response is lower for low skilled and higher for high skilled household when the financing is done through increased progressivity (Case 3) compared to Case 2. Since adjusted gross income (i.e. labor and capital income) is taxed, the necessary increase in the tax schedule to finance the tax credit reform crowds out savings. When progressivity is increased (Case 3), high skilled households systematically reduce their saving more than in the case of a shift in tax schedule (Case 2). Also the low skilled households savings response is lower when progressivity is increased compared to when progressivity is kept constant. Overall, the crowding out ef- 
fect on savings is magnified by the tax schedule response to finance the tax credit expansion.

Effect of transfer generosity on saving and work incentives. A key property of the EITC is its effect on labor force participation. However it is unclear whether increased labor market participation results from the higher incentives to work or from the reduced incentive to save caused by increased tax credit generosity. We decompose the change in participation before and after the extension noted $\Delta H^{1,0}$ as follows:

$$
\begin{aligned}
\Delta H^{1,0} & =\int_{X} \mathbf{1}^{1}(i, a, \epsilon) d \lambda^{1}(i, a, \epsilon)-\int_{X} \mathbf{1}^{0}(i, a, \epsilon) d \lambda^{0}(i, a, \epsilon) \\
& =\underbrace{\int_{X} \Delta \mathbf{1}(i, a, \epsilon) d \lambda^{0}(i, a, \epsilon)}_{\equiv \lambda^{0} \Delta \mathbf{1}}+\underbrace{\int_{X} \mathbf{1}^{1}(i, a, \epsilon) \Delta \lambda(i, a, \epsilon) d X}_{\equiv \mathbf{1}^{1} \Delta \lambda} .
\end{aligned}
$$

where $\lambda^{0} \Delta \mathbf{1}$ is the increase in participation due to higher work incentives holding the distribution constant and $\mathbf{1}^{1} \Delta \lambda$ is the increase in participation solely due to a change in the savings behavior, holding households' participation decision constant. The resulting figures for selected productivity realizations are documented in table 6 . For low income households in both skill groups, the work incentive effect is important and for low skilled households it dominates the insurance effect. This group responds positively to lower average and marginal tax rates, and in the case of low skilled households they use part of the additional income to reduce debt or increase savings (the second effect is negative, while the first is positive). However, for average productivity workers, the incentive effect is dominated, as improved public insurance lowers the marginal benefit of working for the purpose of self-insurance.

These results suggest that intertemporal effects are of second order for low 
income workers who receive the highest transfer payments relative to their income, but they become more important for households with income levels that are at least on the phase-out range of the EITC schedule. This is not entirely surprising as the poorest households in the distribution do not hold savings or may even be borrowing constrained. However, the individual relevance of the two margins and their interaction is an important factor in the evaluation of the program and has so far not been considered in the literature.

\begin{tabular}{cccccccccc}
\multicolumn{4}{c}{ Low Skilled } & \multicolumn{4}{c}{ High Skilled } \\
\hline & \multicolumn{4}{c}{ Low Prod } & \multicolumn{2}{c}{ Avg Prod } & \multicolumn{2}{c}{ Low Prod } & \multicolumn{2}{c}{ Avg Prod } \\
$\eta$ & 1 & 2 & 1 & 2 & 1 & 2 & 1 & 2 \\
\hline \hline 0.1 & 0.0000 & 0.0000 & -0.5427 & 0.8041 & 0.0029 & 0.0037 & -0.0074 & 0.0240 \\
0.25 & 0.4102 & -0.1299 & -1.2042 & 1.7672 & 0.0069 & 0.0085 & -0.0229 & 0.0678 \\
0.5 & 0.4363 & 0.0778 & -2.6128 & 3.9023 & 0.0117 & 0.0159 & -0.0529 & 0.1402 \\
\hline
\end{tabular}

Table 6: Decomposition of the increase in participation for high and low skilled households. Units are in percentage points. Effect due to 1: Higher incentives to work. 2: Lower incentives to save - cf. equation (13).

Wage versus transfer effect. What drives households' responses to increased tax credit generosity? To answer this question, we decompose the effect from increased tax credit generosity into a wage and a transfer effect (figure 4). We isolate the wage effect by solving the model holding the nominal tax credit payment constant and imposing the wage and tax payment that prevails in the post-reform stationary equilibrium. To isolate the transfer effect, we solve the model holding the wage constant at the value of the benchmark equilibrium and we feed the model the tax schedule of the post-reform stationary equilibrium.

Our decomposition shows that households' labor supply response to increased tax credit generosity works mostly via the transfer effect, suggesting that tax 

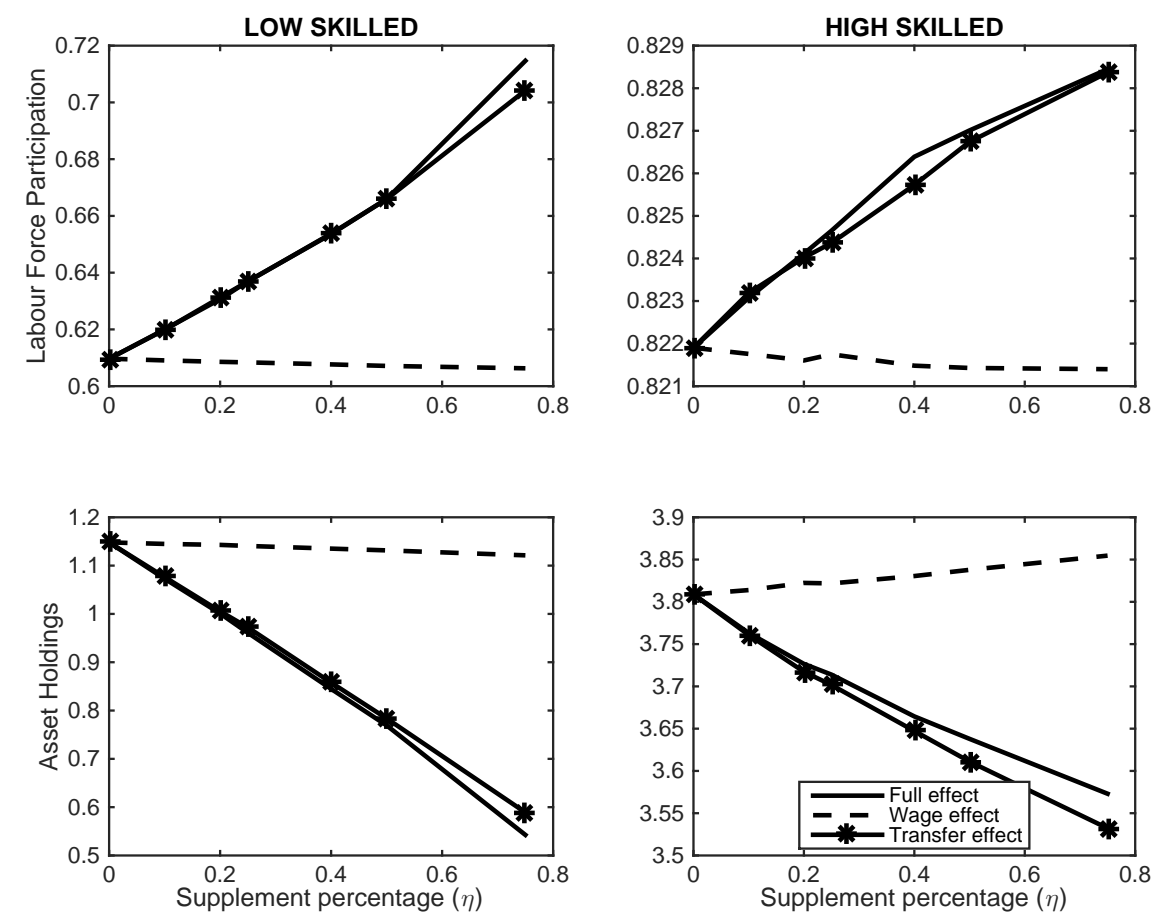

Figure 4: Partial effects of increased tax credit generosity on aggregates by group type.

credit is an effective policy instrument to raise labor force participation. As the two lower panels of figure 4 show, the reduction in private insurance is also driven by the transfer effect. Yet, as highlighted above, the wage effect mitigates the crowding out of savings for the high skilled population, but enhances it for the low skilled population. In this sense, tax credit is an effective policy instrument to raise labor force participation, but it crowds out private savings substantially, in particular for the low skilled population. An important caveat is that the dominance of the transfer effect is to some extent also an endogenous result due to the relative magnitude of changes in wages and tax credits: the change in the wage is smaller than the increase in transfers. Our results confirm the concern on adverse wage responses due to tax credit policies (Meyer, 2010), but highlight that the direct effect dominates on average for the poor low skilled population. However, it is important to distinguish between the targeted population and the 

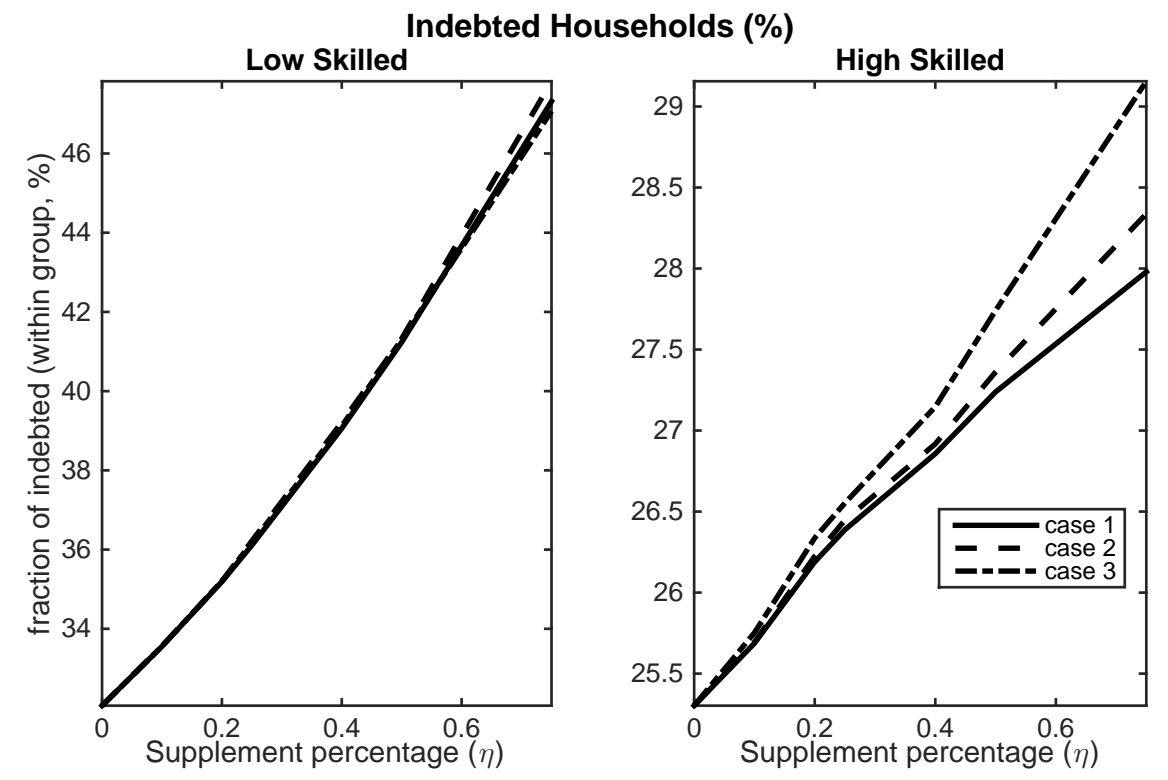

Figure 5: Fraction of indebted households in \%, within group figures.

non-targeted population, as will become clear in our welfare analysis (section $3.2)$.

Figures 5 and 6 shed light on the crowding out effect on private insurance. Figure 5 shows that the fraction of indebted households increases for both skill groups. Aggregating over skill types, it increases from $29 \%$ to $34.9 \%$ when EITC generosity increased by $50 \%(\eta=0.5)$. The composition of households in debt changes as well: whilst in the benchmark economy, $60.76 \%$ households of the indebted are low skilled, they constitute $64.9 \%$ of the population of borrowers for $\eta=0.5$. Figure 6 shows also that while the effect on high skilled households is non-zero, it is negligible for the wealthier (who do not work), it strongly affects wealth holdings of low skilled households throughout the wealth distribution, which contributes to between group wealth inequality and leads to almost $50 \%$ of low skilled households being indebted. 

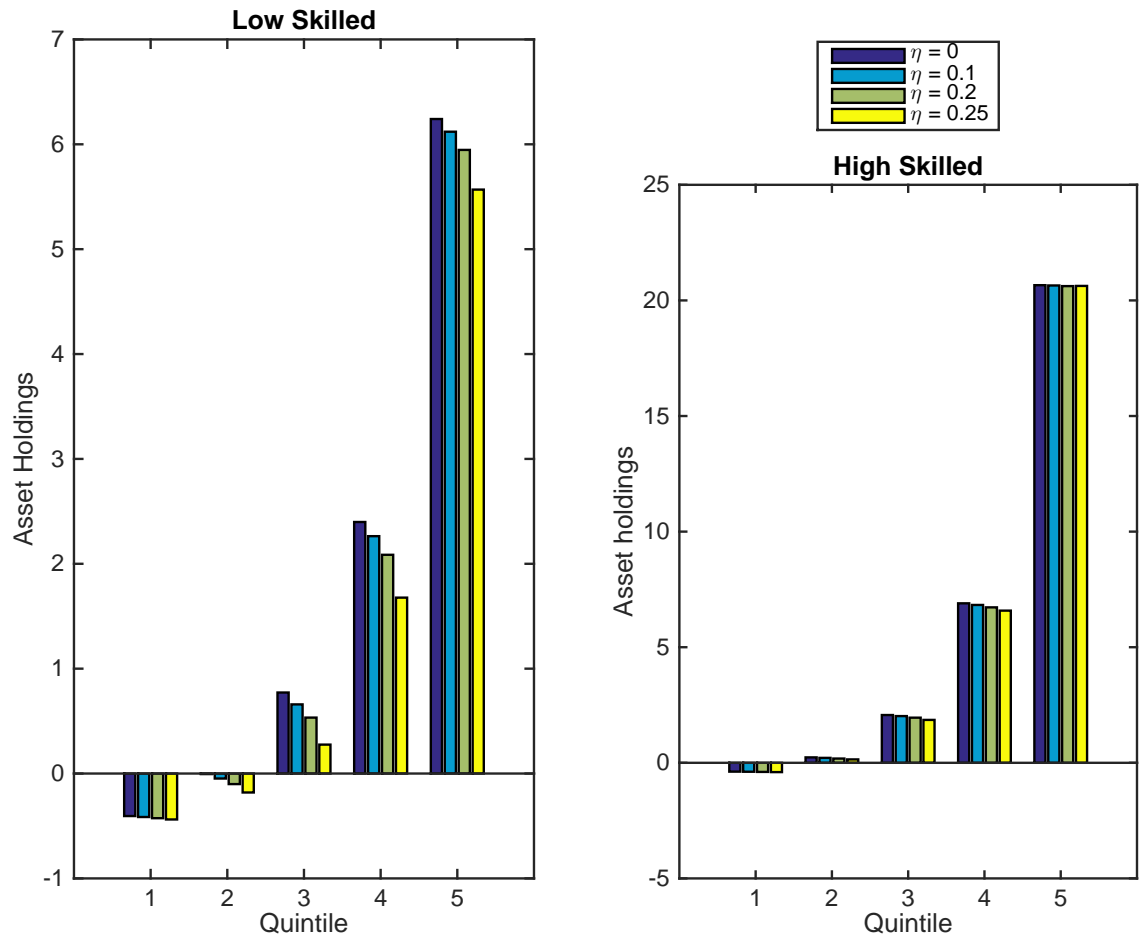

Figure 6: Asset holdings across quintiles for selected expansions in generosity, by skill type, in levels. Left: Low skilled. Right: High skilled. 


\subsubsection{Transition}

To complete our analysis of tax credit policies on economic aggregates, we solve the transition path of the economy after the implementation of an increase in tax credit generosity by $10 \%(\eta=0.1)$. The transition path of the main economic aggregates is reported in figure 7 . In the first period after the reform, labor force participation adjusts downwards sharply. Based on the post reform level of tax credit generosity, households hold more assets than is optimal. As a consequence households reduce their labor supply initially, and dis-save until the economy reaches its new steady state. Such labor supply responses following a wealth effect have been documented in the context of inheritances by Holtz-Eakin et al. (1993). Conversely, as private assets are decumulated, labor supply rises over the transition path to reach the level of labor force participation that is higher than the pre-reform level.

\subsection{Welfare Effects}

This subsection analyzes the welfare implications of the tax credit reform. We offer several measures of individual and aggregate changes to contrast welfare measures across stationary equilibria and along the transition path. For all computations, we employ utilitarian welfare weights. It will become apparent that our results are robust to more general social welfare functions.

The ex post perspective. The ex post perspective on aggregate welfare consists in comparing aggregate welfare across steady states. Denote the difference in aggregate welfare by $\Delta W_{i}^{S S}$, where

$$
W_{i}^{S S}=\int_{A x E x S} V(i, a, \epsilon) d \lambda^{S S}(i, a, \epsilon)
$$

The aggregation uses the distribution of households in the two stationary equilibria. Table 7 reports percentage changes in ex post welfare by skill groups 

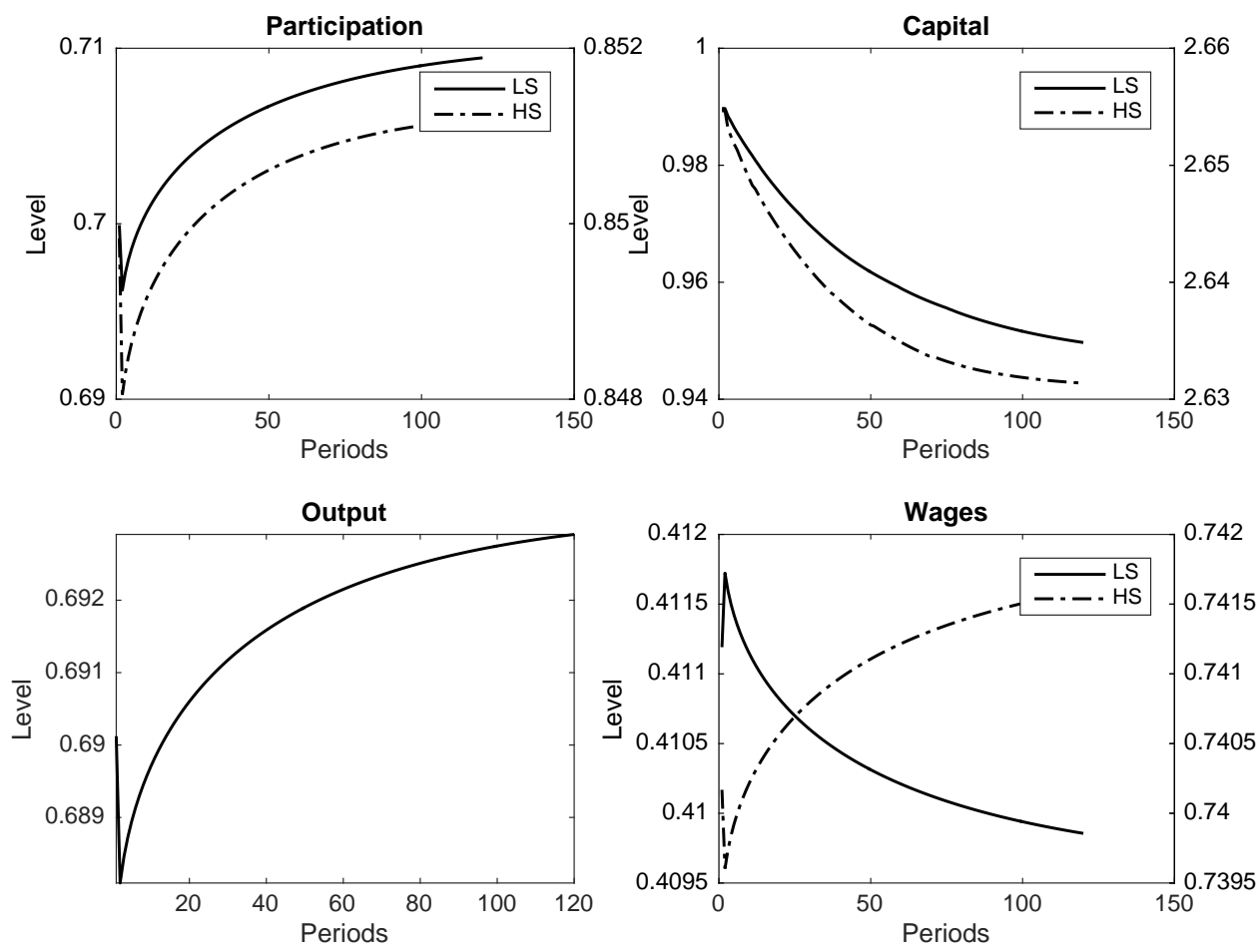

Figure 7: Transition path of the economy after an unanticipated permanent tax credit reform $(\eta=0.1)$. 
and in the aggregate. As the tax credit system is expanded, aggregate welfare falls. This result is driven by low skilled households' welfare, since average welfare for high skilled households increases. Despite an overall fall in wealth levels, welfare in this skill group increases due to two factors: first, as documented in the partial equilibrium section, high skilled households receive a higher wage and are thus able to increase consumption. Second, poorer high skilled households receive higher transfers which improves their insurance against labor productivity shocks, thereby increasing their expected life time utility. The insurance effect is also documented in figure 6 and higher welfare is immediate at least for Case 1 by revealed preferences: As wages and tax credits increase, if households decide to change their asset holdings, they must be better off, since their pre-reform consumption-savings bundle is still in their budget set. Since the probability of becoming eligible for transfers falls with wealth, the wealthier (non-worker) households are largely unaffected by the reform and their expected welfare differences approach zero.

For low skilled household the situation is less clear cut. Ex ante, welfare gains depends on their labour productivity and gross income (AGI) when working. In fact while low productivity households receive relatively more transfers that can offset the negative income effect due to lower low skilled wage, this is not necessarily the case for higher productivity low skilled households, as figure 8 shows.

This negative effect on ex post aggregate welfare is due to a change in the distribution of households, as we showed in figures 5 and 6. Most households actually gain from the extension, except for the higher productivity low skilled households who receive a lower wage and do not benefit much from higher transfers. These welfare losses do not drive the overall fall in welfare: they are dominated by welfare gains for the majority of the population. Total welfare falls 
because the fraction of borrowing constrained households increases by 2.5 p.p. when $\eta=0.5$; their lifetime utility is low enough compared to unconstrained households to outweigh individual welfare gains.

The ex-ante perspective. We now turn to the discussion of ex ante welfare and results that take into account the transition to the new stationary equilibrium. Equations (15) defines these measures. $\omega_{\text {transition }}$ is an aggregate of discounted expected lifetime utility after an unexpected increase in EITC generosity, while $\omega_{\text {ex-ante }}$ aggregates discounted expected lifetime utility before the reform takes place. $^{24}$

$$
\begin{aligned}
\omega_{\text {transition }} & =\int_{I x A x E}\left(\frac{V_{\eta}^{t=1}(i, a, \epsilon)}{V_{\eta=0}^{S S}(a, \epsilon, s)}-1\right) d \lambda_{\eta=0}^{S S}(i, a, \epsilon) \\
\omega_{\text {ex-ante }}= & \int_{I x A x E}\left(\frac{V_{\eta}^{S S}(i, a, \epsilon)}{V_{\eta=0}^{S S}((i, a, \epsilon)}-1\right) d \lambda_{\eta=0}^{S S}(i, a, \epsilon)
\end{aligned}
$$

We report the welfare results in table 8. The first welfare metric (see 'Transition' header) contrasts the indirect utility in the initial steady state with the indirect utility in the period after the reform that takes into account the transition - this measure is conditional on the state of the household when the reform is implemented. In figure 8 and table 7 we provide more disaggregated information and document percentage changes in welfare by productivity, skill types and across quintiles of the income distribution. ${ }^{25}$

From an ex-post perspective, all high skilled households gain from the reform:

\footnotetext{
${ }^{24}$ Notice that since the wealth distribution is fixed at the time of the reform, both measures use the same probability density functions.

${ }^{25}$ These results are for the unfunded expansion scenario. While results do not change qualitatively irrespective of the financing choice for the range of credit expansions considered in the paper for ex ante welfare, we are not providing results for the transition with funded expenditure here.
} 

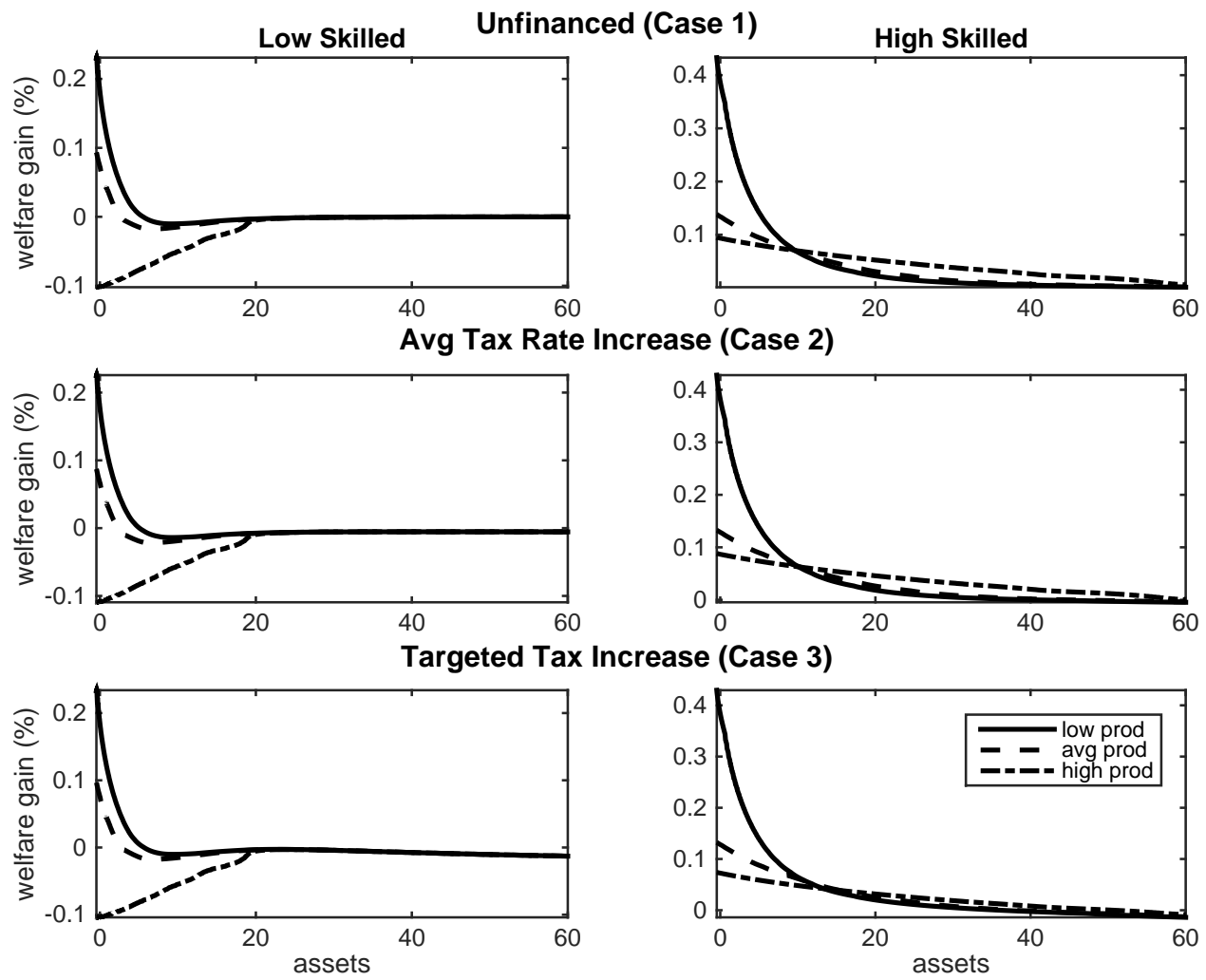

Figure 8: Welfare Gains by Productivity type for $\eta=0.1$

if they work they either receive a transfer or earn a higher wage and if they do not work, they barely reduce assets (see figure 6) since they are too wealthy to qualify for tax credits. Low skilled households gain if they are in the lower part of the income distribution; otherwise, the transfer income does not offset their lower wage income due to the fall in the wage rate. In fact, table 7 shows that welfare gains are highest for very poor and households in the second quintile. While the former are often borrowing constrained and the transfer effectively relaxes their borrowing constraint, the latter receive the most effective boost in public insurance.

The results conditional on the reform being implemented provide some interesting qualitative and quantitative differences with respect to the ex ante results. Overall, the result for welfare remains unchanged (see table 8), however, welfare 


\begin{tabular}{cccccccccc} 
& \multicolumn{3}{c}{ Low Skilled } & \multicolumn{3}{c}{ High Skilled } & \multicolumn{3}{c}{ Aggregate } \\
$\eta$ & Case 1 & Case 2 & Case 3 & Case 1 & Case 2 & Case 3 & Case 1 & Case 2 & Case 3 \\
\hline \hline & & \multicolumn{1}{c}{ Ex Post Welfare } \\
0.1 & -0.26 & -0.27 & -0.26 & 0.07 & 0.06 & 0.04 & -0.12 & -0.13 & -0.14 \\
0.25 & -0.54 & -0.59 & -0.55 & 0.16 & 0.11 & 0.03 & -0.25 & -0.30 & -0.31 \\
0.5 & -1.20 & -1.28 & -1.20 & 0.38 & 0.26 & 0.03 & -0.55 & -0.64 & -0.69 \\
0.1 & 0.03 & 0.03 & 0.03 & 0.13 & 0.13 & 0.12 & 0.08 & 0.07 & 0.07 \\
0.25 & 0.11 & 0.09 & 0.12 & 0.31 & 0.28 & 0.28 & 0.20 & 0.18 & 0.19 \\
0.5 & 0.21 & 0.17 & 0.24 & 0.64 & 0.58 & 0.56 & 0.40 & 0.36 & 0.38 \\
\hline \hline
\end{tabular}

Table 7: Welfare Gains (\%) for selected generosity expansions. Ex post differences in upper part, ex ante in lower. See text for definitions.

gains are from this perspective more widespread in the population.

All high skilled households gain, irrespective of their probability of receiving the transfer. If they receive the transfer, they gain because they receive additional funds. If they do not because they fail the asset test but are working, they still gain because their wage increases over the medium term. In the short run, the wage falls as explained in the previous section. This is why (a) the increase in $V$ is higher across stationary equilibria, and (b) it affects a much larger fraction of households. Since high skilled households experience a negative income effect initially when the reform is implemented, a significant proportion of their long term welfare gains is washed out, in particular for those who will most likely never benefit from the reform.

Low skilled households also gain from higher tax credit generosity because (a) their consumption profile becomes smoother due to increased transfer payments, and (b) as a related effect, their precautionary demand for assets falls and overall consumption increases. Contrary to high skilled wages, low skilled wages fall in the medium to long term. This is why also wealthier households now gain from the reform: short term boosts to earned income and thus consumption (as 
assets are depleted) offset the long term fall in wages, which is relatively less pronounced.
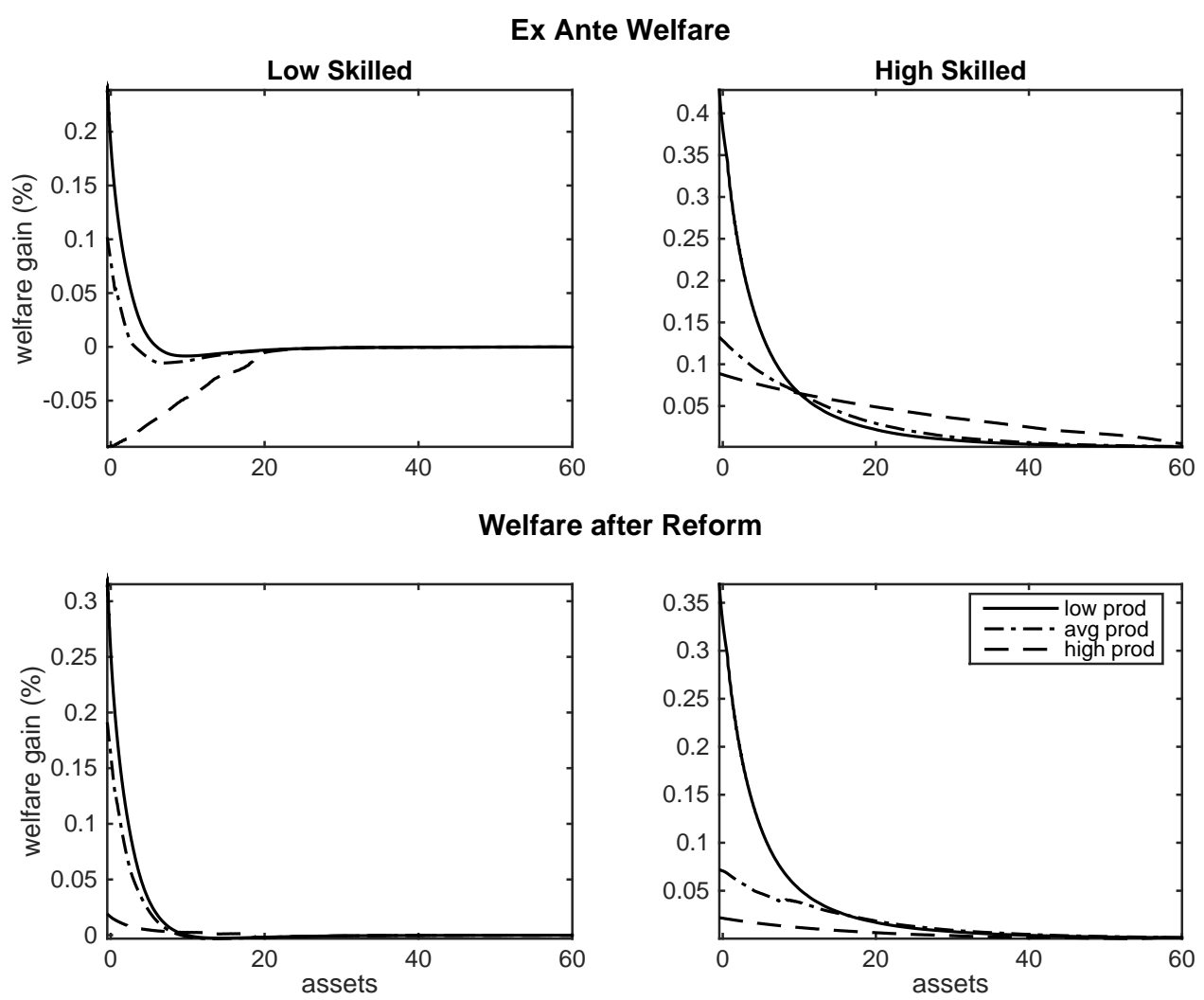

Figure 9: Difference in expected lifetime utility. Up: After implementation of reform. Down: Across stationary equilibria.

\section{Conclusion}

This paper bridges the empirical literature on the EITC and the literature on taxation with household heterogeneity to conduct a positive analysis of the EITC. While the research on tax credit is dense, we know little about its effect on individuals' savings decision, and on its redistributive impact, in particular towards individuals that are not directly affected by tax credit policies. We quantify the labor supply, wage and savings responses of a once and for all EITC extension across stationary equilibria and on the transition path. 


\begin{tabular}{l|rrrrrr} 
& \multicolumn{6}{|c}{ Change in Welfare (\%) } \\
& \multicolumn{4}{|c}{ Transition } & \multicolumn{4}{c}{ Ex Ante SS } \\
\hline \hline Quantile & Agg & LS & HS & Agg & LS & HS \\
\hline \hline 10\% & 0.13 & 0.18 & 0.17 & 0.18 & 0.28 & 0.53 \\
Quintile 1 & 0.13 & 0.12 & 0.16 & 0.21 & 0.15 & 0.51 \\
Quintile 2 & 0.17 & 0.18 & 0.08 & 0.33 & 0.28 & 0.34 \\
Quintile 3 & 0.08 & 0.15 & 0.05 & 0.13 & 0.19 & 0.25 \\
Quintile 4 & 0.04 & 0.08 & 0.04 & 0.12 & -0.01 & 0.21 \\
Quintile 5 & 0.02 & 0.02 & 0.02 & 0.12 & -0.13 & 0.15 \\
Aggregate & 0.09 & 0.11 & 0.07 & 0.18 & 0.10 & 0.29 \\
\hline \hline
\end{tabular}

Table 8: Welfare Changes Aggregate and by Type across quintiles. Agg = Aggregate, LS = Low Skilled, HS = High Skilled

Our results show that the EITC successfully redistributes income towards the poor working population without distorting incentives to work. However, the tax credit reduces the incentive to save for a large part of the targeted population and increases the propensity of poor working households to indebt themselves. Both effects of the tax credit have non trivial distributional effects: the increase in labor supply contributes to an increase of the skill premium, and the crowding out of savings leads to an increase in wealth inequality. Our analysis is more nuanced and shows that the EITC might contribute to a widening the wage gap, but that for the eligible population, these adverse wage effects are dominated by the direct transfer effect of tax credits. As for the ineligible population that is indirectly affected by the negative wage effects, we show that when we take into account transitional dynamics, a large part of the wage drop is compensated by a short run increase in wages and higher consumption in the long term due to the depletion of savings along the transition path. Our welfare analysis shows that a majority of the population benefits from tax credit policies, except for the high income households within the low skilled population. Once we take into account transitional dynamics, a large extent of these welfare losses disappear.

Looking forward, our results motivate further empirical research into the im- 
portance of the intertemporal margin of the behavioral response to the EITC. Our analysis could be extended and generalized in several dimensions. First, by incorporating single households, further predictions could be made about the relative importance of intertemporal and labor supply effects, and their macroeconomic implications. In particular the latter has not been addressed by the studies that focus on aggregate effects. Second, allowing for more fix cost types would, on the one hand, improve the fit of the distribution of households along the EITC schedule and, on the other hand, it would produce a richer distribution of fix cost-productivity pairs among EITC recipients, as is observed in the data. 


\section{Bibliography}

Ábrahám, Árpád and Eva Cárceles-Poveda, "Endogenous trading constraints with incomplete asset markets," Journal of Economic Theory, may 2010, $145(3), 974-1004$.

Aiyagari, S. Rao, "Uninsured Idiosyncratic Risk and Aggregate Saving," The Quarterly Journal of Economics, aug 1994, 109 (3), 659.

Athreya, Kartik, Devin Reilly, and Nicole Simpson, "Young Unskilled Women and the Earned Income Tax Credit : Insurance Without Disincentives ?," The Federal Reserve Bank of Richmond - Working Paper Series, 2014, WP $14-11 R$.

Blundell, R, Mc Dias, C Meghir, and J Shaw, "Female labour supply, human capital and welfare reform," NBER Working Paper No. 19007, 2015.

Blundell, Richard, "Earned income tax credit policies: Impact and optimality," Labour Economics, 2006, 13 (4), 423-443.

_ and HW Hoynes, "Has In-Work Benefit Reform Helped the Labour Market ?," in R. Blundell, D. Card, and R.B. Freeman, eds., Seeking a Premier Economy: The Economic Effects of British Economic Reforms, 1980-2000, University of Chicago Press, 2004, pp. 411-459.

Chetty, Raj, John N. Friedman, and Emmanuel Saez, "Using differences in knowledge across neighborhoods to uncover the impacts of the EITC on earnings," American Economic Review, 2013, 103 (7), 2683-2721.

Conesa, Juan Carlos and Dirk Krueger, "On the optimal progressivity of the income tax code," Journal of Monetary Economics, 2006, 53 (7), 1425-1450. 
_ , Sagiri Kitao, and Dirk Krueger, "Taxing Capital? Not a Bad Idea after All!," American Economic Review, 2009, 99 (1), 25-48.

Crossley, Thomas F. and Hamish Low, "Borrowing constraints, the cost of precautionary saving and unemployment insurance," International Tax and Public Finance, 2011, 18 (6), 658-687.

Domeij, David and Jonathan Heathcote, "On the distributional effects of reducing capital taxes," International Economic Review, apr 2004, 45 (2).

Eissa, Nada and Hilary Hoynes, "Redistribution and tax expenditures: The earned income tax credit," National Tax Journal, 2011, 64 (June), 689-730.

_ and Hilary W. Hoynes, "Behavioral Responses to Taxes : Lessons from the EITC and Labor Supply," Tax Policy and the Economy, 2006, 20, 73-110.

- and Jeffrey B. Liebman, "Labor Supply Response to the Earned Income Tax Credit," The Quarterly Journal of Economics, 1996, 111 (2), 605-637.

_ , Henrik Jacobsen Kleven, and Claus Thustrup Kreiner, "Evaluation of four tax reforms in the United States: Labor supply and welfare effects for single mothers," Journal of Public Economics, apr 2008, 92 (3-4), 795-816.

Engen, Eric M. and Jonathan Gruber, "Unemployment insurance and precautionary saving," Journal of Monetary Economics, 2001, 47 (3), 545-579.

Feldstein, Martin, "The Effect of Marginal Tax Rates on Taxable Income: A Panel Study of the1986 Tax Reform Act," Journal of Political Economy, 1995, $103(3), 551-572$.

Gouveia, Miguel and Rovert P. Strauss, "Effective federal individual income tax functions: An exploratory empirical analysis," National Tax Journal, 1994, $47(2), 317-339$. 
Guner, N., R. Kaygusuz, and G. Ventura, "Taxation and Household Labour Supply," The Review of Economic Studies, 2012, 79 (3), 1113-1149.

Guner, Nezih, Remzi Kaygusuz, and Gustavo Ventura, "Income Taxation of U . S . Households: Facts and Parametric Estimates," Review of Economic Dynamics, 2013, (December).

Heathcote, Jonathan, "Fiscal Policy with Heterogeneous Agents and Incomplete Markets," Review of Economic Studies, jan 2005, 72 (1), 161-188.

_ , Fabrizio Perri, and Giovanni L. Violante, "Unequal we stand: An empirical analysis of economic inequality in the United States, 19672006," Review of Economic Dynamics, jan 2010, 13 (1), 15-51.

_ , Kjetil Storesletten, and Giovanni L. Violante, "Quantitative Macroeconomics with Heterogeneous Households," Annual Review of Economics, sep 2009, 1 (1), 319-354.

_ , _ , and Giovanni L Violante, "The Macroeconomic Implications of Rising Wage Inequality in the United States," Journal of Political Economy, 2010, $118(4), 681-722$.

_ , _ , and Giovanni L. Violante, "Optimal Tax Progressivity: An Analytical Framework," CEPR Discussion Paper, 2014, 9866.

Holter, Hans, Dirk Krueger, and Serhiy Stepanchuk, "How Does Tax Progressivity and Household Heterogeneity Affect Laffer Curves?," 2014.

Holtz-Eakin, Douglas, David Joulfaian, and Harvey S. Rosen, "The Carnegie Conjecture: Some Empirical Evidence," Quarterly Journal of Economics, 1993, 108 (2), 413-435. 
Hotz, V Joseph and John Karl Scholz, "The Earned Income Tax Credit," in Robert A. Moffitt, ed., Means-Tested Transfer Programs in the United States, Vol. I, University of Chicago Press, 2003.

Hubbard, R.G., J. Skinner, and S.P. Zeldes, "Precautionary Saving and Social Insurance," The Journal of Political Economy, 1995, 103 (2), 360-399.

Huggett, Mark, "The risk-free rate in heterogeneous-agent incompleteinsurance economies," Journal of economic Dynamics and Control, 1993, 17 (5-6), 953-969.

Krueger, Dirk and Alexander Ludwig, "On the Optimal Provision of Social Insurance," Working paper, 2015.

Krusell, Per, Lee E. Ohanian, Jose-Victor Rios-Rull, and Giovanni L. Violante, "Capital-skill Complementarity and Inequality: A Macroeconomic Analysis," Econometrica, sep 2000, 68 (5), 1029-1053.

Leigh, Andrew, "Who Benefits from the Earned Income Tax Credit? Incidence among Recipients, Coworkers and Firms," The B . E . Journal of Economic Analysis 83 Policy Advances, 2010, 10 (1).

Meyer, BD and DT Rosenbaum, "Welfare, the earned income tax credit, and the labor supply of single mothers," The Quarterly Journal of Economics, 2001, (August), 1063-1114.

Meyer, Bruce D., "Labor Supply at the Extensive and Intensive Margins: The EITC, Welfare, and Hours Worked," American Economic Review, 2002, 92 (2), 373-379.

Meyer, Bruce D, "The Effects of the Earned Income Tax Credit and Recent Reforms," NBER Working Paper, 2010, 24 (August). 
Murphy, Kevin and Lawrence Katz, "Changes in Relative Wages, 1963-1987 : Supply and Demand Factors," The Quarterly Journal of Economics, 1992, $107(1), 35-78$.

Nichols, Austin and Jesse Rothstein, "The Earned Income Tax Credit," NBER Working Paper, 2015, 21211.

Oh, Hyunseung and Ricardo Reis, "Targeted transfers and the fiscal response to the great recession," Journal of Monetary Economics, dec 2012, 59, S50-S64.

Rothstein, Jesse, "Is the EITC as Good as an NIT? Conditional Cash Transfers and Tax Incidence," American Economic Journal Economic Policy, 2010, 2 (1), $177-208$.

Saez, Emmanuel, "Optimal Income Transfer Programs: Intensive Versus Extensive Labor Supply Responses," Quarterly Journal of Economics, 2002, 117 (3), 1039-1073.

Slavík, Ctirad and Hakki Yazici, "Machines, buildings, and optimal dynamic taxes," Journal of Monetary Economics, 2014, 66, 47-61.

Tauchen, G, "Finite state markov-chain approximations to univariate and vector autoregressions," Economics Letters, 1986, 20 (2), 177-181.

Weber, Caroline E, "Does the Earned Income Tax Credit Reduce Saving by Low-Income Households?," Working paper, 2014. 


\section{Appendix A. Appendix}

Appendix A.1. A time series perspective on federal transfer programs

Over the past 20 years, within the U.S. federal budget, a compositional shift towards transfers away from investment has taken place (Oh and Reis, 2012), to the point that transfer programs are the most prominent federal fiscal policy instrument in the United States. As of 2011, transfers amount to $43 \%$ of total government spending. To gauge the relative importance of transfer policies, we plot in figure A.10b the fiscal policy instruments as ratios of the federal budget allocated to benefits to persons. Disaggregating the federal government expenditure in transfers (federal benefit to persons) by program highlights the emergence of refundable tax credits as the most important transfer program alongside with unemployment insurance. Since 1990 the share of budget of federal benefits allocated to refundable tax credits was multiplied by a factor of 6 . The promotion of tax credit policies was motivated by the belief that tax credit is a policy instrument that can simultaneously increase labor force participation and raise real relative wages of the low skilled. As suggested by Blundell (2006) this was a key rationale behind the surge of tax credit policies.

Appendix A.2. The Earned Income Tax Credit (EITC)

The EITC has, along side unemployment insurance, become an essential redistribution policy in the United States. Since its introduction in 1975, it steadily expanded, and the number of eligible recipients has increased rapidly to reach in 2008, about 25 million, at a total cost to the federal government of $\$ 51$ billion (Eissa and Hoynes, 2011; Hotz and Scholz, 2003).

The EITC is a mean-tested transfer program, meaning households have to satisfy specific economic criteria to be eligible (See table A.9 for a full list of those criteria, and figure A.11 for a graphical representation of the tax credit 
Figure A.10: Time series perspective of US federal government transfer programs. Transfers are defined as the sum of social benefits, subsidies and capital transfers.

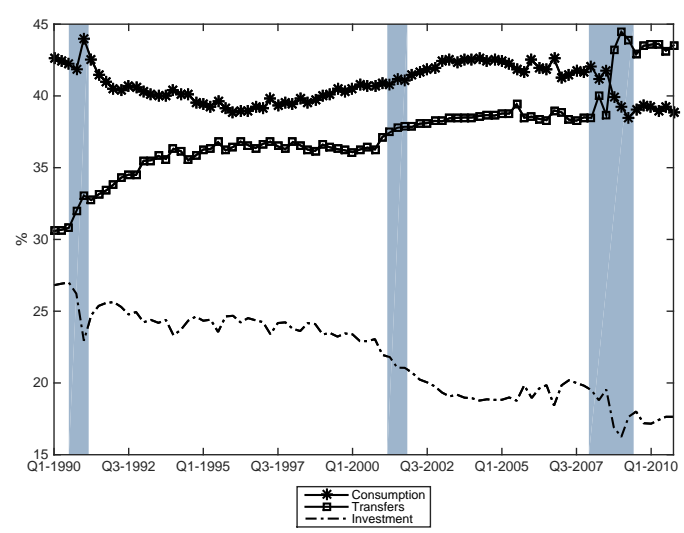

(a) Decomposition of U.S. Government Expenditure (19902010)

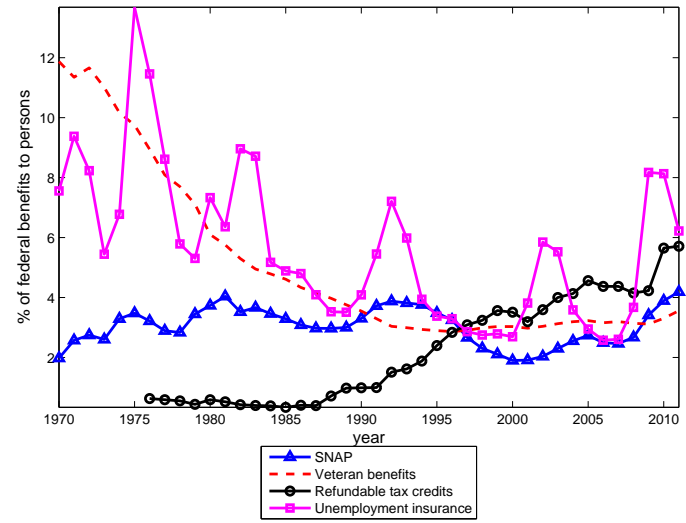

(b) Shares of selected transfer categories in total federal social benefits, 1970-2012. Source: BEA NIPA table 3.12.

Table A.9: Eligibility criterion for the Earned Income Tax Credit program

- Earned and Adjusted Gross Income (AGI) that is positive but below a threshold, that varies by filing status and family size as can be seen in figure A.11).

- A qualifying child must be younger than 19 (24 if student or disabled).

- Claimant must be parent / grandparent / foster child.

- Child must live at least 6 months with the tax payer.

- Sum of interest, dividends, net capital gains, rents and royalties must be less than $\$ 3,100$.

schedule). The amount of tax credit perceived is a function of the households earned income (Adjusted Gross Income), the filing status, and number of eligible children as depicted in figure A.11. With regard to total annual earned income, the total tax credit schedule has three distinct regimes. In the first so-called phase-in regime, the tax credit acts as a subsidy on earnings. In the second regime, tax credit are invariant with earnings, and finally in the third regime, the 
phase-out regime, tax credit are a negative function of earnings. Also the EITC pay-off is conditional on the household's capital income not being higher than a specified threshold, 3,100 US\$. ${ }^{26}$

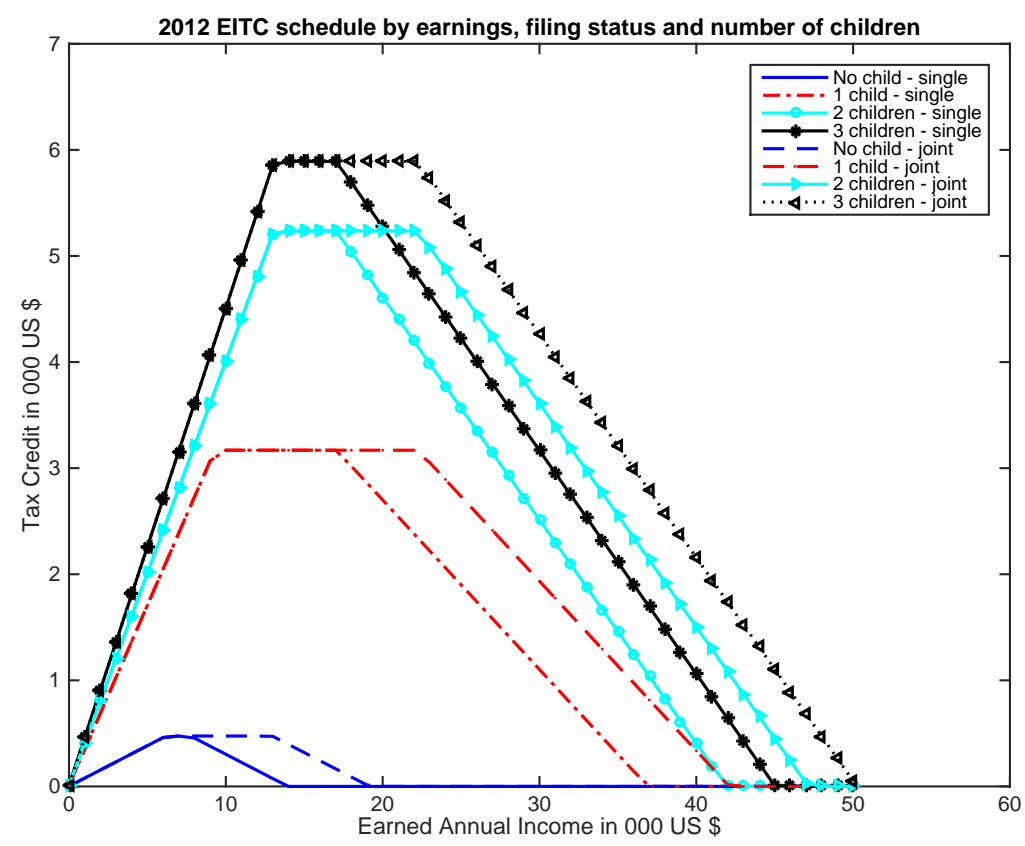

Figure A.11: EITC schedule. Source: Department of Treasury - Internal Revenue Service Publication 596

\footnotetext{
${ }^{26}$ For a complete documentation of the EITC we refer the reader to Nichols and Rothstein (2015) \& Meyer (2010)
} 